\title{
ADMINISTRAÇĀO ESPECIFICA
}

\section{O Tráfego e sua Repercussão no Urbanismo (*)}

\section{Geraldo de MEnezes Côrtes}

\section{CAPítulo vin}

\section{OS TRANSPORTES}

\section{INTRODUÇÃo}

$\mathrm{O}_{\mathrm{S}}$ meios próprios de locomoção do homem têm suas limitaçōes naturais, no cansaço fisico e na demora para vencer grandes deslocamentos. Êles bastam à vida de uma vila, mas quando crescem as distâncias só os meios de transporte, animais e mecânicos, podem atender às necessidades humanas.

Quanto maiores as distâncias, mais a rapidez dos meios de transporte cresce de importância e o homem busca, incessantemente, maior velocidade nêles, como recurso de um prolongamento artificial da própria vida. Por isto assistimos à progressiva substituiçăo dos meios animais de transporte, pelos mecânicos, e o crescente aperfeiçoamento dêstes. Os diferentes tipos de transporte coexistirão, no entanto, devido à complexidade da vida das Comunidades e ao fato de serem várias as necessidades de seus diversos habitantes, dos que trabalham nas fábricas, dos que comerciam, dos que têm algo a carregar ou transportar, dos que labutam nos escritórios e nos laboratórios, dos que se dedicam às atividades agropecuárias, dos que estudam ou ensinam, dos que buscam as casas de diversōes ou os campos esportivos, dos que procuram as igrejas para confôrto espiritual, dos que residem longe ou perto dos locais onde precisam ir ou de onde retornam, dos que se deslocam em horas conhecidas e regulares, ou imprevistas, de dia ou de noite, etc.

Alguns meios de transporte individual são comuns em tôdas as cidades, mas outros, mais que os coletivos, constituem verdadeiros característicos regionais, porque encontram suas origens em certas atividades humanas, estāo vinculados ao padrão de vida de seus utilizadores, dependem da topografia e das condiçōes das vias de comunicaçōes por onde transitam e resistem, longos anos, às substituiçōes por outros meios mais confortáveis e mesmo mais convenientes.

O meio de transporte individual mais generalizado nos grandes centros urbanos, do mundo moderno, é inegàvelmente o automóvel, muito embora, na

(*) Retomamos neste número a publicação dos capítulos finais do trabalto sob o título supra, interrompida em setembro de 1954). 
maior parte das pequenas cidades brasileiras e na zona rural, o cavalo e o muar sejam ainda considerados os principais meios de transporte individual. A proporção que melhoram as vias de comunicaçōes e a capacidade econômica dos indivíduos, os animais de sela e as pequenas viaturas de tração animal vão sendo substituidos pela bicicleta, pela motocicleta e pelo automóvel.

O caminhão vem sendo o campeão nos transportes de carga, especialmente nos centros urbanos. Nas ligaçōes terrestres interestaduais e intermunicipais, dia a dia, o transporte motorizado se desenvolve e passa a coexistir ao lado das ferrovias, seja pelo indispensável complemento que a rigidez destas não pode dispensar, seja pela preferência, muito natural, que por êle têm certas cargas. Apesar de tudo isto, em nossas pequenas cidades e na zona rural, o transporte de carga ainda não dispensou as carroças de burro ou puxadas a cavalo e até mesmo os carros de boi, para nảo falarmos nos burros ou nos cavalos de carga.

Nas zonas rurais especialmente, tornam-se necessários os transportes que deveremos chamar mistos, isto é, aquêles que ao mesmo tempo servem às pessoas $\mathrm{e}$ às mercadorias. Os furgōes $\mathrm{e}$ os pick-ups săo as réplicas modernas das cangalhas mistas, ainda hoje observadas nas pequenas cidades nordestinas, as quais servem de sela para o cavaleiro e também o transporte de pequenas cargas, seja com os caçuás ou com os ganchos laterais.

Os transportes das pessoas (individuais ou coletivos) e os das mercadorias, êstes conhecidos como transportes de carga, podem ter caráter particular, isto é, a serviço exclusivo dos respectivos proprietários, ou caráter público, isto é, à disposição de terceiros, mediante remuneração específica.

Conforme o local em que se processa o transporte, êle pode ser urbano ou intermunicipal, servindo, neste último caso, às conexōes entre as cidades. A zona rural às vêzes é atendida pelo transporte intermunicipal $\mathrm{e}$, outras vêzes, possui meios próprios complementares dos transportes urbanos, para as necessárias conexōes com a regiăo suburbana ou para a exclusiva satisfaçăo das necessidades desta ou daquela área.

Antigamente, quando inexistiam transportes públicos, cada um precisava promover seus próprios meios de transporte e, ainda hoje, quanto piores os transportes públicos, mais se apela para os transportes particulares. E a consequêencia natural é que o aperfeiçoamento do sistema de transportes coletivos possibilita a crescente diminuiçấo do uso dos transportes individuais, mais onerosos e, por isto mesmo, dificilmente ao alcance de todos. Esta verdade, de importância no campo social, nảo pode ser esquecida, ao revés, deve merecer sempre uma atenção especial.

Històricamente, os primeiros transportes públicos surgiram para ligar as cidades, e só a partir do século XIX, inclusive, com o desenvolvimento e crescimento das cidades, começaram a nascer os diversos tipos de transportes urbanos. As Estradas de Ferro substituiram, com vantagem, as diligências de tração animal na ligação das grandes distâncias, mas no século atual, os ônibus já concorrem com o trem ferroviário, como excelente meio de transporte coletivo entre as cidades e os autocaminhōes; devido à flexibilidade que possuem, saem algumas vêzes do campo de natural complemento do transporte ferroviário para o campo competitivo com êste. Levando de porta a porta a mer- 
cadoria transportada, o autocaminhäo ganha em tempo, e, às vêzes, também seu custo global se torna mais vantajoso do que o transporte através de estrada de ferro, apesar do frete de Estaçāo a Estação ferroviária ser muito mais baixo que o rodoviário.

Algumas cidades ao se desenvolverem, chegaram a conhecer como primeiro meio de transporte coletivo os ônibus de traçáo animal, mas, na generalidade delas, o bonde puxado a burro foi o pioneiro do transporte coletivo, até que no último decênio do século XIX surgiu o bonde elétrico e, logo a seguir, começamos a apelar para os trens suburbanos, como meio de ligação rápida entre os subúrbios e os centros comerciais (ou zonas centro) das grandes cidades.

O desenvolvimento das linhas de bonde estêve, assim, intimamente ligado ao crescimento das populaçōes urbanas, até que os meios de transporte automotores vieram oferecer o seu concurso, no transporte das pessoas e das mercadorias, ao mesmo tempo que reclamar novas e excepcionais medidas do urbanismo moderno, a que já nos referimos ao tratar do Planejamento das Cidades.

Os primeiros ônibus começaram a preencher as lacunas entre as linhas de bonde e as zonas de desenvolvimento urbano por elas ainda não servidas e, posteriormente, passaram a concorrer com os bondes, de acôrdo com suas características próprias, especialmente de maior velocidade e flexibilidade.

Depois dos bondes e coexistindo com êles, surgiram os rápidos trens urbanos, em estrutura elevada ou correndo no subsolo, muito conhecidos como metropolitano, metrô ou sub-way.

Os bondes também foram, progressivamente, melhorando de tipo quanto a velocidade, confôrto dos passageiros e eliminaçảo de ruídos, até chegar ao trolley-bus ou trolley-coach, que começam a ser conhecidos no Brasil como ônibus elétricos.

Finalmente, os táxis e outros transportes especiais como o de escolares e o individual através do arrendamento de veículos são dignos de atenção.

\section{OS TRANSPORTES COLETIVOS URBANOS}

\section{1 - As necessidades e o lucro}

O centro e os diversos bairros de uma cidade não oferecem as mesmas condiçōes de lucro para os transportes coletivos, porque diferentes săo as distâncias a percorrer, o estado da pavimentação das pistas e a demanda de lugares, conseqüente, principalmente, da desigualdade de densidade populacional existente em cada bairro e também da maior concentração humana observada, temporária e diàriamente, mais no centro comercial de uma cidade, do que em qualquer um de seus bairros. Se vários forem os exploradores de transporte coletivo para o atendimento do centro e das ligaçōes dêste com cada bairro e entre alguns bairros, fatalmente haverá os privilegiados, os mais bem aquinhoados e uma tendência à admissão de tarifas diferentes, para equilibrar a margem de lucro diante da diversidade de operação, como ocorre no Rio de Janeiro, atualmente. No entanto, todos os habitantes da cidade precisam, 
indistintamente, de transporte e anseiam por pagar um mesmo preço baixo pelas passagens, qualquer que seja o local para onde ou de onde se transportam e a hora em que o fazem.

\section{2 - Preço único - Lei das compensações - Critérios tarifários}

O atual sistema de transportes coletivos do Rio de Janeiro não oferece ao público passagem a preço único, porque existem inúmeras emprêsas de ônibus, micro-ônibus e também exploradores individuais dos transportes coletivos.

Numa área urbana, o mais conveniente para a coletividade é o transporte a preço único porque, se quisermos que paguem menos os que percorrem distâncias menores e os que residem em áreas de melhor calçamento e de maior densidade demográfica, ocorrerá também o reverso, isto é, pagarão mais os que residem nas zonas mais distantes, de pior calçamento e de menor densidade demográfica, via de regra os menos protegidos pela sorte, os de menor renda. Assim, o preço único, englobando tôda a zona urbana, sem distinção, é uma imposição de grande alcance social.

A lei das compensaçōes, aliás, é a arma de que se pode lançar mão para possibilitar transporte, năo só em locais deficitários, mas em horas e oportunidades inconvenientes do ponto de vista econômico, o que, indiscutivelmente, interessa à coletividade, porque o transportado nâo precisa se preocupar com o lucro ou o prejuizo do transportador, no momento em que êste the serve. O transporte é a mola impulsionadora do progresso e mesmo nas horas mortas do dia ou da noite, uma parte da populaçäo precisa de transporte.

Existe uma infinidade de critérios para as tarifas dos transportes coletivos em geral. O mais generalizado no Brasil, embora nāo o preferivel do ponto de vista de melhor servir às coletividades urbanas, é o diferencial na base quilométrica. "Tanto maior o percurso, mais se deve pagar e vice-versa", assim pensam muitos. Aparentemente parece justo e, portanto, correto êste critério. $\mathrm{Na}$ realidade o é, para os transportes coletivos entre cidades, quando pràticamente nâo há renovação de passageiros. Mas, nas zonas urbanas, o mais razoável e o que mais beneficia a coletividade é a tarifa única, independente das distâncias percorridas, devido à compensaçấo da renovação de passageiros. Aliés, a "American Transit Association" considera o critério do preço único, como uma caracteristica fundamental das passagens nos transportes urbanos.

Para a obtenção da tarifa única é preciso que os cálculos apreciem os cômputos gerais e globais do serviço e seu rendimento. Naturalmente, que a tarifa quilométrica é mais simples de calcular, tem um aparente rigor matemático, mas o resultado de sua aplicação exclusiva nos transportes urbanos é a elevação do valor das passagens que o público pagará, acima do que seria possivel e razoável, se considerarmos o cômputo geral do rendimento que um serviço unificado propiciaria, quando encarado como um todo e quando a unificação da propriedade dos meios de transporte proporciona o máximo partido das benéficas consequiências da lei das compensaçōes.

Nas cidades norte-americanas tem prevalecido o critério da tarifa única, não sem protesto dos que consideram "iniqüidade pagar-se uma mesma passagem para o transporte de curtas e de longas distâncias". De vez em quando, 
tem sido proposto naquelas cidades, sem lograr grande aceitação, o critério do pagamento de passagens de acôrdo com as zonas percorridas, como tentativa de relacionar o valor da passagem à distância da viagem e, portanto, mais ligada ao custo direito desta. Argumentam que êste é o critério nos diversos tipos de transporte - ferroviário, aéreo, táxis, ônibus intermunicipais etc., onde o sistema tarifário parte de cálculo na base da lotaçāo, do coeficiente de aproveitamento desta e dos quilômetros percorridos. Na Inglaterra e em outros países europeus, o sistema de pagamento de passagens de acôrdo com as zonas percorridas é generalizado. Alguns julgam que o êxito dêste sistema, na Europa, se deve ao fato de haver em cada veículo um cobrador além do motorista ou motorneiro e que a resistência ao dito sistema, encontrada na América do Norte, decorre das dificuldades de cobrança por zonas, mantendo em cada veículo um só homem, o motorista ou motorneiro. Estamos, no entanto, convictos de que é de ordem social o verdadeiro alcance do preço único e por isto devemos resistir à multiplicidade de tarifas numa área urbana de acôrdo com as zonas atravessadas, como vem acontecendo no Rio de Janeiro.

Nẫo se tem conseguido através dos anos, ainda, unanimidade de vistas quanto à estrutura ideal para as tarifas dos transportes coletivos urbanos.

A estrutura de uma tarifa ideal é a que concilia o interêsse do público que quer serviço adequado ao mais baixo preço possível, e o interêsse da emprêsa de obter adequada renda sôbre o capital empregado, para continuar a operar. Segundo a American Transit Association, a estrutura de uma tarifa ideal deve:

- Proporcionar adequada renda à emprêsa.

- Atender ao apêlo popular da Comunidade de passagens razoàvelmente baixas que sejam prontamente compreensiveis e de uso simples.

- Ser de fácil cobrança.

- Ser suficientemente flexível, quando envolver a cobrança de mais de um valor.

- Visar ao aumento do fator carga.

- Permitir passagens seletivas para vários grupos de passageiros para incrementar o fator uso. Os grupos para os quais estas passagens seletivas podem ser aplicadas são:

- passageiros ocasionais;

- passageiros regulares;

- passageiros de todos os dias;

- passageiros de curta distância;

- passageiros das horas mortas ou de fora dos períodos de pico de tráfego;

- passageiros de domingos e feriados;

- passageiros crianças e estudantes.

O "Centro Técnico Consultivo Ltda.", sediado no Rio de Janeiro e conhecido pela sigla C.E.T.E.L. e composto de um grupo de Engenheiros Construtores e Supervisores de Serviços de Utilidade Pública, propugna pelo cálculo da tarifa básica para os transportes coletivos urbanos na base do carro-quilômetro 
por passageiro, segundo naturalmente os preços e custos atualizados do serviço de ônibus.

Em seus cálculos, o C.E.T.E.L. considera que os juros do capital invertido e a depreciação dos ônibus devem ser computados na base de juros compostos em vez de juros simples, por ser aquela a forma correta de cômputo de cargas fixas de capital. Para o C.E.T.E.L, a vida média útil de um ônibus deve ser considerada de 5 anos e o lucro comercial calculado na base de $12 \%$ do capital de operação, invocando a lei $\mathbf{n}^{\circ} \mathbf{7 7 5}$.

O processo C.E.T.E.L. de cálculo da tarifa é o de composição de custos em funçẫo de indice de referência, obtidos através da análise de resultado de operaçăo. O processo é análogo ao indicado para o cálculo de tarifa para serviço de táxis do Distrito Federal, no Decreto n. ${ }^{\circ} 31.181$, de 25 de julho de 1952, bem como análogo ao adotado oficialmente no D.N.E.R. (Departamento Nacional de Estradas de Rodagem) e em outros Departamentos Estaduais de Estradas de Rodagem.

Transcreveremos, a seguir, os cálculos realizados pelo C.E.T.E.L., em $1 .^{\circ}$ de março de 1955, para justificar um pedido de aumento de tarifas das emprêsas de ônibus operando no Rio de Janeiro e assistidas tècnicamente por aquêle Centro.

Elementos considerados nos cálculos:

1. Onibus de referência Volvo, de 43 passageiros sentados e 25 em pê.

2. Custo atual do ônibus novo, Cr\$ 1.200,000,00.

3. Vida útil do ônibus de referência, $\mathbf{5}$ anos.

4. Valor residual do ônibus no fim da vida útil, $\mathrm{Cr} \$ 240.000,00$.

5. Taxa de juros compostos do capital invertido e depreciação dos veículos, $10 \%$ ao ano.

6. Lucro justo do capital de operação (Lei 775), $12 \%$ ao ano.

7. Coeficiente de aproveitamento de lugares oferecidos, julgado compativel com o serviço adequado, $75 \%$. metros.

8. Percurso médio anual por veículo da frota licenciada, 90.000 quilô-

9. Custo do capital invertido no almoxarifado expresso em têrmos do capital de veículos, $15 \%$.

10. Quota por ônibus-ano do capital invertido em imóveis e instalaçōes fixas de garagem, $\mathrm{Cr} \$ 15,000,00$.

11. Salário diário do motorista, $\operatorname{Cr} \$ 160,00$.

12. Salário diário do trocador, $\mathrm{Cr} \$ 80,00$.

13. Salário diário do despachante, $\mathrm{CrS} 130,00$.

14. Salário médio do pessoal de oficinas, $\mathrm{Cr} S 130,00$.

15. Salário médio do pessoal do escritório, $\mathrm{Cr} \$ 100,00$.

16. Eficiência humana em homens-hora por $1.000 \mathrm{~km}$, motorista ou trocador, 80 .

17. Idem, idem do despachante, 8 .

18. Idem, idem do pessoal das oficinas, 90 .

19. Idem, idem do pessoal do escritório, 20 .

20. Custo do pneumático por unidade, $\mathrm{Cr}$ S $8.232,00$. 
21. Idem das câmaras de ar, $\mathrm{Cr} \$ 771,00$.

22. Idem de uma recapagem, $\mathrm{Cr} \$ 2.650,00$.

23. Vida média dos pneumáticos e uma recapagem, 45.000 quilômetros.

24. Custo médio dos lubrificantes, por litro, Cr\$ 16,00 .

25. Rendimento médio dos lubrificantes, em $\mathrm{km} / \mathrm{litro}, 40$.

26. Custo do combustivel, por litro, $\mathrm{Cr} \$ 1,32$.

27. Rendimento do combustivel em $\mathrm{km} /$ litro, 2,5.

28. Legislação social expressa em \% da mão de obra, nas seguintes componentes, dando um total de 44,9 .

- Previdência, 7,0

- L.B.A., 0,5

- Sesi, 2,0

- Senai, 1,0

- Férias, 5,8

- Folgas remuneradas, 16,6

- Indenizaçôes, aviso prévio, e auxílio doença, 12,0 .

29. Seguro contra acidentes de tráfego, por ônibus/ano, Cr\$ $33.000,00$. 30. Taxas, impostos, licenças e Petrobrás por ônibus/ano, $\mathrm{Cr} \$ 12.000,00$.

31. Administração e Engenharia por ônibus/ano, Cr\$ 20.000,00. $5 \%$.

32. Contingência de operação, expressa em \% do custo de operação,

Componentes dos custos de exploraçāo do Carro/quilômetro:

A - Cargas fixas de capital

\section{Componentes:}

1 - Juros do capital invertido nos veículos.

2 - Depreciaçăo dos veículos.

3 - Juros do capital invertido no almoxarifado.

4 - Quota relativa ao capital invertido em imóveis e instalaçōes.

5 - Lucro do capital invertido.

\section{Juros do capital invertido nos veículos}

O capital invertido é a diferença entre o valor atual do ônibus novo e o valor residual do mesmo, no fim de sua vida útil:

Cr\$ $1.200 .000,00-\operatorname{Cr} \$ 240.000,00=\operatorname{Cr} \$ 960.000,00$.

Fórmula dos juros compostos: $\mathrm{A}=\mathrm{P}(1+\mathrm{R})^{\mathrm{n}}$ em que

$\mathrm{P}$ - o principal, é igual a $\mathrm{Cr} \$ 960.000,00$;

$\mathbf{R}$ - a taxa de juros ao ano, é igual a 0,10 ;

$\mathrm{n}$ - o número de anos de vida útil, é igual a 5 ;

A - a quantia correspondente ao Principal acrescida dos juros compostos, no fim de $n$ anos.

$\mathrm{A}=\mathrm{Cr} \$ 960.000,00(1+0,10)^{5}$

$\log A=\log 960.000: 5 \times \log 1,10$ 
$\mathrm{A}=\mathrm{Cr} \$ 1.446 .000$

Importância correspondente aos juros compostos:

Cr\$ $1.446 .000-\operatorname{Cr} \$ 960.000=\operatorname{Cr} \$ 486.000,00$

No fim de 5 anos, o percurso respectivo é de $5 \times 90.000 \mathrm{~km}=450.000$ carro/quilômetros.

Custo por carro/quilômetro:

$$
\frac{\operatorname{Cr} \$ 486.000}{450.000}=\operatorname{Cr} \$ 1,077
$$

2. Depreciação dos veículos

Fórmula da depreciação:

$$
\mathrm{D}=\frac{\mathrm{R}(1-\mathrm{Tn})}{\mathrm{Tn}} \mathrm{em} \text { que: }
$$

D - taxa de depreciaçăo anual do capital correspondente à diferença entre os valores atual e residual do ônibus novo.

$\mathrm{R}-$ taxa anual dos juros compostos.

$\mathrm{T}$ - fator têrmo:

$$
\mathrm{T}=1-\frac{1}{(1+\mathrm{R})} \mathrm{n}
$$

$\mathrm{n}$ - número de anos de vida útil, do veículo.

$$
\mathrm{D}=\frac{0,10(1-0,37908)}{0,37908}=16,38 \%
$$

Custo da depreciação ao ano é igual a $0,1638 \times 960.000-$ Cr\$ $\ldots \ldots$. $157.000,00$.

Custo por carro/quilômetro é igual a

$$
\frac{\mathrm{Cr} \$ 157.000}{90.000}=\operatorname{Cr} \$ 1,720
$$

3. Juros do capital invertido no almoxarifado

Correspondendo o valor médio do estoque do almoxarifado a $15 \%$ do valor original dos veículos, o custo quilométrico será de $0,15 \times \mathrm{Cr} \$ 1,077=$ Cr\$ 0,162. 
4. Quota de capital invertido em imóveis e instalaçōes

Considerando que Cr\$ $15.000,00$ é a quota por ônibus/ano e que $90.000 \mathrm{~km}$ é o percurso anual do ônibus, a influência desta quota por carro/quilômetro será de

$$
\begin{array}{r}
\text { Cr\$ } 15.000 \\
90.000
\end{array}
$$

5. Lucro do capital invertido

Os custos do capital correspondem a $\mathrm{Cr} \$ 1,077+1,720+0,162+$ $+0,167=\mathrm{Cr} \$ 3,126$

Logo o lucro do capital por carro/quilômetro será de $0,12 \times 3,126=$ - Cr\$ 0,384

O custo das cargas fixas de capital por carro/quilômetro é de $\operatorname{Cr} \$ 3,126+$ $+\mathrm{Cr} \$ 0,384=\mathrm{Cr} \$ 3,510$. (I).

\section{B - Custo de Operação}

Componentes:

1 - Custos diretos

2 - Custos indiretos

1. Custos diretos de operação

a) Pessoal-Tráfego

Salário/hora do motorista, Cr\$20,00

Eficiência humana -80 homens/hora por $1000 \mathrm{~km}$

Custo por quilômetro do motorista é de

$$
\frac{80 \times 20,00}{1.000}-\operatorname{Cr} \$ 1,60
$$

Salário/hora do trocador, $\mathrm{Cr} \$ 10,00$

Eficiência humana - 80 homens/hora por $1.000 \mathrm{~km}$

Custo por carro/quilômetro do trocador é de

$$
\frac{80 \times 10,00}{1.000}=\operatorname{Cr} \$ 0,80
$$

Salário/hora do despachante, $\operatorname{Cr} \$ 11,25$

Eficiência humana -8 homens/hora por $1.000 \mathrm{~km}$ Custo por carro/quilômetro do despachante

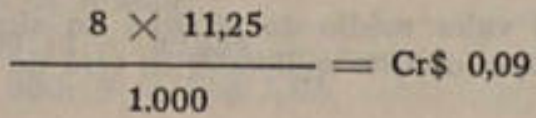


Custo por carro/quilômetro do pessoal do tráfego:

$$
\operatorname{Cr} \$ 1,60+\operatorname{Cr} \$ 0,80+\operatorname{Cr} \$ 0,09=\operatorname{Cr} \$ 2,49
$$

\section{b) Pessoal-Oficinas}

Salário/hora média do pessoal de oficinas, Cr\$ 16,25

Eficiência humana - 90 homens/hora por $1.000 \mathrm{~km}$ Custo por carro/quilômetro

$$
\frac{90 \times 16,25}{1.000}=\operatorname{Cr} \$ 1,465
$$

\section{c) Pessoai-Escritório}

Salário/hora médio do pessoal do escritório, $\mathrm{Cr} \$ 12,50$ Eficiência humana -20 homens/hora por $1.000 \mathrm{~km}$ Custo por carro/quilômetro

$$
\frac{20 \times 12,50}{1.000}=\operatorname{Cr} \$ 0,250
$$

Custo total do Pessoal por carro/quilômetro

$$
\mathrm{Cr} \$ 2,49+\mathrm{Cr} \$ 1,465+\mathrm{Cr} \$ 0,250=\mathrm{Cr} \$ 4,205
$$

d) Pneumáticos e Câmaras de ar

Custo de 6 pneumáticos novos.......6 x Cr\$ 8.232,00 $=\operatorname{Cr} \$ 49.392,00$

Custo de 6 câmaras de ar novas.....6 $\times$ Cr\$ $771,00=\mathrm{Cr} \$ 4.626,00$

Custo de 6 recapagens...........6 $\times$ Cr\$ $2.650,00-\mathrm{Cr} \$ 15.900,00$

Custo total do calçamento do ônibus................ $=\mathrm{Cr} \$ \mathbf{6 9 . 9 1 8 , 0 0}$ Custo do carro/quilômetro para uma vida média de $45.000 \mathrm{~km}$ para o calçamento do ônibus

$$
\frac{69.918,00}{45.000}=\operatorname{Cr} \$ 1,555
$$

e) Peças e Acessórios

Custo segundo os preços atuais no meio da vida do ônibus por carro/ quilômetro $\mathrm{Cr} \$ 2,50$

f) Combustivel

Preço por litro, Cr\$ 1,32

Rendimento médio por litro, $2,5 \mathrm{~km}$

Custo por carro/quilômetro

$$
\frac{1,32}{2,5}-\operatorname{Cr} \$ 0,527
$$




\section{B) Lubrificantes}

Custo médio por litro, $\mathrm{Cr} \$ 16,00$

Rendimento por litro, $40 \mathrm{~km}$

Custo por carro/quilômetro *

$$
\frac{16,00}{40}=\operatorname{Cr} \$ 0,40
$$

h) Näo classificados

Estimativa de $\mathrm{Cr} \$ 0,20$ por quilômetro

Total dos custos diretos de operação por carro/quilômetro

$\operatorname{Cr} \$ 4,205+\operatorname{Cr} \$ 1,555+\operatorname{Cr} \$ 2,50+\operatorname{Cr} \$ 0,527+\operatorname{Cr} \$ 0,40+\operatorname{Cr} \$ 0,20=$ $=\operatorname{Cr} \$ 9,387$ (II)

2. Custos indiretos de operaçäo

a) Legislaçäo social

Conforme exposto na referência 28 dos Elementos de cálculo, corresponde a $44,9 \%$ da mão de obra

Custo por carro/quilômetro é de 0,449 $\times \mathrm{Cr} \$ 4,295-\mathrm{Cr} \$ 1,894$
b) Taxas - Impostos - Licenças e Petrobrás

Conforme exposto na referência 30 dos Elementos de cálculo, corresponde a $\mathrm{Cr} \$ 12.000,00$ por ônibus/ano

Custo por carro/quilômetro é de $\mathrm{Cr} \$ 12.000,00 \div 90.000-\mathrm{Cr} \$ 0,133$

c) Seguros e indenizaçōes de trátegó

Conforme exposto na referência 29 dos Elementos de cálculo, corresponde a $\mathrm{Cr} \$ 33.000,00$ por ônibus/ano

Custo por carro/quilômetro é de $\mathrm{Cr} \$ 33.000,00 \div 90.000=\mathrm{Cr} \$ 0,367$

d) Administraçăo e engenharia

Conforme exposto na referência 31 dos Elementos de cálculo, corresponde a Cr\$ 20.000,00 por ônibus/ano.

Custo por carro/quilômetro é de $\mathrm{Cr} \$ 20.000,00 \div 90.000-\mathrm{Cr} \$ 0,222$

e) Luz - Fôrça - Telefone

Cr\$ 2.000,00 por ônibus-ano.

Custo por carro/quilômetro é de

$\frac{\operatorname{Cr} \$ 2.000}{90.000}=\operatorname{Cr} \$ 0,022$




\section{f) Contingéncias}

Conforme exposto na referência 32 dos Elementos de cálculo, corresponde a $5 \%$ do custo total de operaçăo, excluindo contingências:

$\mathrm{Cr} \$ 9,387+\mathrm{Cr} \$ 1,894+\mathrm{Cr} \$ 0,133+\mathrm{Cr} \$ 0,367+\mathrm{Cr} \$ 0,222+\mathrm{Cr}_{2} \$ 0,022=$ $=\operatorname{Cr} \$ 12,025$

Custo por carro/quilômetro é de $0,05 \times \mathrm{Cr} \$ 12,025=\mathrm{Cr} S 0,601$

Custo total das despesas indiretas de operaçấo por carro/quilômetro:

$\operatorname{Cr} \$ 1,894+\operatorname{Cr} \$ 1,133+\operatorname{Cr} \$ 0,367+\operatorname{Cr} \$ 0,222+\operatorname{Cr} \$ 0,022+\mathrm{Cr} \$ 0,601=$ $=\mathrm{Cr} \$ 3,239$ (III)

Resumo dos custos por carro/quilômetro:

A) Cargas fixas de capital: $\mathrm{Cr} \$ 3,510$ (I)

B) Custo de operaçăo:

1. $\left.{ }^{\circ}\right)$ Diretos -

\begin{tabular}{|c|c|c|}
\hline Pessoal $\ldots \ldots$. . & $\mathrm{Cr}$ S & 4,205 \\
\hline Material . . . . . . . . . . . . & $\mathrm{Cr} \$$ & 5,182 \\
\hline Total . . ...... & $\mathrm{Cr} S$ & $\begin{array}{l}9,387 \\
3,30\end{array}$ \\
\hline $\left.2 .^{\circ}\right)$ Indiretos $\ldots \ldots \ldots \ldots \ldots$ & $\mathrm{Cr} \$$ & 3,239 \\
\hline
\end{tabular}

Logo, o custo geral de exploraçăo (cargas fixas mais custo de operação) 6 de $\operatorname{Cr} \$ 16,136$.

Tarifa básica por carro/quilômetro:

A fórmula da tarifa básica é

$$
\mathrm{Tq}=\frac{\mathrm{Ce}}{\mathrm{P} \times \mathrm{K}} \text { em que }
$$

Tq é a tarifa básica por carro/quilômetro, por passageiros, e em cruzeiros

Ce é o custo geral de exploração do serviço por carro/quilômetro em pé)

P é a capacidade total do veículo de referência (passageiros sentados e

K é o coeficiente de aproveitamento de lugares oferecidos

Para os valores referidos e calculados

$$
\mathrm{Tq}=\frac{\operatorname{Cr} \$ 16,136}{68 \times 0,75}=\operatorname{Cr} \$ 0,321
$$

por carro/quilômetro e por passageiro. 
Ao apresentar o cálculo supra transcrito, o C.E.T.E.L. prestou outros esclarecimentos sob o título "Instruçōes para a formaçāo dos preços de passagens nas linhas de ônibus":

"A tarifa acima é diretamente' aplicável à quase totalidade das linhas de ônibus do Rio de Janeiro. No entanto, há linhas cujo percurso médio anual e coeficiente de aproveitamento de lugares oferecidos se afastam substancialmente dos índices médios de referência. Exemplos dessas exceções são as linhas circulares do centro da cidade, as linhas de Laranjeiras e Catete ou linhas muito curtas. Nestas linhas deverão ser determinadas as características particulares e aplicadas à tarifa, procedendo-se a novo cálculo. De um modo geral as linhas de baixa velocidade comercial, como o caso das linhas circulares centrais, o percurso médio anual por veículo da frota deverá ser computado com 50.000 quilômetros, a capacidade do veículo de referência em 45 passageiros e o coeficiente de aproveitamento de lugares em $85 \%$.

"Na formação dos preços de passagem, tais preços deverăo ser referidos à área de operação e não ao comprimento próprio da linha a fim de estimular a operação de boosters dentro de cada área. Assim, por exemplo, o preço de passagem na área da Tijuca deve ser o mesmo, quer o ponto inicial seja na Usina, na Muda, ou em qualquer outro local dentro daquela área.

"A seleção dos preços de passagem deverá ser adotada para eliminar ou reduzir a interferência entre transportes de áreas diferentes, mas nunca dentro da mesma área seletiva.

"Os secionamentos dos preços de passagem deverăo ser adotados sòmente quando se tornar conveniente a elevaçăo do mercado de passageiros, como condiçāo para a elevação de frequuência ou quando o transporte direto não assegurar o coeficiente de aproveitamento de $75 \%$."

Não temos objeções, quanto à justeza matemática do cálculo do custo geral de operação. $\mathrm{O} x$ da questão está no Coeficiente $\mathrm{K}$ "de aproveitamento de lugares oferecidos", na fórmula para o cálculo da tarifa básica por carro/ quilômetro $\mathrm{Tq}=\frac{\mathrm{Ce}_{\mathrm{e}}}{\mathrm{P} \times \mathrm{K}}$. Aliás, é o próprio C.E.T.E.L. quem o reconhece.

Sabido que nas zonas urbanas e especialmente na parte de seu centro comercial a renovaçäo de passageiros proporciona um lucro substancial, sempre que a tarifa tiver sido calculada abaixo da lotação normal, fácil é compreender que o critério do cálculo apresentado, correto para uma ligaçâo rodoviária entre cidades e mesmo entre a zona central e subúrbios distantes, não deve ser seguido na avaliaçăo da tarifa para os transportes coletivos urbanos.

A decisão sôbre a fixação da tarifa justa deverá levar em conta a operação global, o balanço geral da emprêsa, para encontrar o preço único para as passagens em tôda a área urbana.

\section{3 - Linhas duplas ou linhas simples?}

Numa Comunidade urbana, o maior volume de passageiros é entre cada bairro e o centro comercial, mas um certo número de passageiros tem interêsse em ser transportado de um bairro a outro. Como a distância dos bairros 
Aa centro comercial nẫo é a mesma e diferente também é a demanda de passageiros de cada bairro, o número de lugares que se deve oferecer por hora não é o mesmo, na ligaçāo bairro-centro comercial, nem tampouco igual pode ser o número de veículos aí empregados, ou seja a freqüência dêles, na linha, por hora.

Após estas consideraçōes, fácil é concluir que as linhas duplas só correspondem a uma soluçấo econômica racional, quando ocorre a coincidência excepcional de serem iguais em relaçāo ao centro, as distâncias a percorrer e as demandas de passageiros dos bairros ligados entre si e através do dito centro, ou coraçăo comercial da cidade. Ainda que essa coincidência excepcional pudesse ser observada generalizadamente, numa cidade de completo desenvolvimento simétrico, impraticável se tornaria proporcionar as múltiplas, inúmeras e totais combinaçōes de linhas duplas, capazes de propiciar a todos que - desejarem, transporte sem baldeação, pois que com transportes coletivos é impossivel levar todos os passageiros aos locais para os quais desejam ir.

Para atendermos, então, às ligações de bairro a bairro, de uma maneira econômica e racional, sem elevaçäo do custo de passagem, devemos recorrer de um modo geral ao estabelecimento das diferentes linhas simples necessárias, só admitindo linhas duplas no caso de equilibrio entre seus dois ramos, mas recorrendo, em qualquer caso, para as múltiplas necessidades, ao bilhete de transíerência.

Nas grandes cidades, como é o caso do Rio de Janeiro, alguns pequenos ramais, linhas ou circulares, que nâo atravessam o centro comercial e nem a èle conduzem, também se tornam necessários, para melhor complementação do sistema de transportes urbanos e estabelecidos de acôrdo com a demanda dos passageiros a que, normalmente, servem. Também nesses ramais convém a, adoção dos bilhetes de transferència, para conectá-los com as linhas de ligação com o centro comercial da cidade.

A linha dupla, permitindo viagens continuas e evitando baldeaçōes, atende bem a certas necessidades do público e, no Rio de Janeiro, devido ao critério tarifário adotado, oferecem uma passagem inferior à soma de duas passagens simples que cobrissem o mesmo percurso. A maior reação do público à extinçäo das linhas duplas decorre da inexisténcia dos bilhetes de transferência, que proporcionam prosseguimento da viagem sem aumento de despesa.

\section{$2.4-$ Bilhete de transferéncia}

O bilhete de transferência é recurso largamente utilizado nos sistemas de transporte coletivo das cidades norte-americanas, para permitir uma organizaçâo racional e econômica do serviço. Na grande maioria dos casos, os billhetes de transferência sâo expedidos sem qualquer pagamento adicional. $O$ objetivo é possibilitar ao passageiro o uso de dois ou mais veículos para uma viagem continuada numa mesma direçāo geral. Normalmente fixam um lapso de tempo dentro do qual o bilhete de transferência deve ser utilizado e aṕs o qual se invalida. Algumas emprêsas só admitem a utilização dos bilhetes de transferência em determinados pontos ou cruzamentos de transferéncia e nunca em outros pontos não discriminados. Tanto existem emprêsas que só admitem a utilização do bilhete de transferência em um único novo percurso 
em segundo veiculo, como em mais de um, quer com o mesmo bilhete, quer trocando-o por outros.

Como o bilhete tem valor intrínseco, habilitando a viajar quem o apresente, tem havido abusos. As restriçóes horárias e de locais para transferência visam a diminuir os abusos, como também com o mesmo objetivo chegaram a introduzir a cobrança de uma adicional no ato da obtenção do bilhete de transferência pelo passageiro que o solicitar. Os principais abusos são: interrupção voluntária da viagem, coleta de bilhetes năo utilizados para revenda a interessados ou coleta por alguns comerciantes que passam a distribuir os ditos bilhetes de transferência aos fregueses, como atraçāo especial para a preferência que esperam obter.

A cobrança do adicional tem servido bem para evitar os abusos, mas é preciso que ela não se torne artifício para aumento substancial da renda, porque isto comprometeria o objetivo de assegurar preço único. Aliás, convém aqui salientar que năo devemos ser ortodoxos, a ponto de em caso algum admitir tarifas diferenciadas por zonas e, conseqüentemente, cobrança de adicional para obtençāo dum bilhete de transferência. Conhecendo os inconvenientes e as vantagens do critério, é possivel a admissāo de exceçōes ainda para atender ao interêsse geral. Por exemplo: imaginemos o nosso Rio de Janeiro atendido por uma única Emprêsa de Transportes Coletivos. Dada a extensāo da cidade e a elevada concentraçăo do centro comercial, seria admissível que o transporte assegurado por circulares no centro tivesse uma passagem muito mais baixa que a tarifa geral única para a ligaçäo com os bairros. A flexibilidade seria assegurada sem aumento de custo, garantindo-se com um bilhete de transferência da viagem de bairro, uma viagem na circular central e, vice-versa, pudesse o pagamento de uma passagem na circular dar direito a um bilhete de transferencia para prosseguir viagem para um bairro, mas, neste caso, graças ao pagamento de um adicional para integralizar o custo desta, no ato de obtençāo do bilhete de transferência.

\section{5 - Expressos - Áreas seletivas - Escalonamento de pontos terminais}

O serviço expresso destina-se ao transporte de passageiros de um a outro local distante, sem paradas intermédias para embarque ou desembarque de passageiros. $\mathrm{O}$ sistema já tem sido instituido em algumas cidades norte-americanas, e, onde canais de tráfego podem ser utilizados, êle se torna extremamente prático, sempre que há demanda de passageiros para a lotação completa do veículo, obtendo-se apreciáveis reduçōes no tempo normal do percurso em relaçāo àquele em que as paradas intermédias são admitidas. $\mathrm{O}$ efeito psicológico de longos percursos sem paradas estimula, realmente, a utilização do serviço de transportes coletivos.

O serviço por áreas seletivas tem outro objetivo, e já tem sido empregado em algumas cidades. $O$ objetivo é igualar, tanto quanto possível, para os residentes das diferentes partes ao longo de um mesmo itinerário, as oportunidades de obtençăo de lugares nos meios de transporte coletivo. Indo para o centro comercial da cidade pela manhā os ônibus recebem passageiros num certo número de paradas (dentro da área que thes couber) e depois nāo recebem mais, embora possam continuar a parar para desembarque de passageiros. Retornando à tarde não descarregam passageiros, até alcançar a área a que 
devem servir, embora possam continuar parando para apanhar passageiros. Desta forma os passageiros são grupados e se desencorajam de utilizar ônibus que o planejamento geral não thes destinou.

Escalonando os pontos terminais ao longo de um itinerário, especialmente nos períodos de "rush" matutino e de fim do dia de trabalho também conseguimos não só oferecer oportunidades de lugares aos residentes ao longo do percurso, mas obter melhor rendimento de lugares oferecidos ao público com um mesmo número de veículos disponíveis, pois que com a redução dos percursos para uma parte da frota, que não precisa ir ao fim da linha, teremos maior número de viagens $\mathrm{e}$, portanto, maior número de lugares hora oferecidos.

As combinaçōes de serviço expresso, áreas seletivas (também conhecidas como serviço limitado) e escalonamento dos pontos terminais são aconselháveis, mas só săo realmente praticáveis se todos os veículos pertencerem a uma emprêsa, do contrário são inevitáveis as reclamaçōes dos prejudicados, ou dos menos aquinhoados, e quem sofre é o público que não se beneficia dessa racionalização do sistema. No Rio de Janeiro, por exemplo, enquanto coexistirem muitos empresárics e inúmeros exploradores individuais de micro-ônibus (impròpriamente chamados lotaçōes) todos êsses recursos técnicos de racionalização do sistema de transportes serāo inviáveis. As combinaçōes de serviço expresso, áreas seletivas e escalonamento de pontos terminais, às vêzes, só convém nos períodos de pico do tráfego. O regime seletivo combinado com o expresso, permitindo que os ônibus recolham passageiros em determinadas áreas e tomem destino certo, prefixado, sem atender aos transportes locais intermédios, é análogo ao sistema tão comum adotado no aproveitamento des elevadores de um grande edificio de muitos andares.

\section{6 - Livre competição ou monopólio - Coordenação}

A livre competiçāo é representada pela exploração individual ou de múltiplas emprêsas e o monopólio corresponde ao serviço por emprêsa única.

Com múltiplas emprêsas ou com exploradores individuais dos transportes coletivos, cada linha ou ramal do sistema urbano precisa, por si só, proporcionar lucro a quem o explora.

Sem descermos a maiores detalhes, não resta dúvida que o preço do transporte deve ser resultante, pelo menos, de duas grandes componentes: o custo operacional e a justa remuneraçăo do capital empregado. Mas o custo de operaçấo só poderá ser baixo se, obedecendo ao princípio econômico da concentração, tivermos uma emprêsa de $\mathbf{X}$ unidades, por exemplo, em vez de $\mathbf{X}$ diferentes proprietários. A emprêsa única poderá baixar o custo operacional, organizando o indispensável serviço de manutenção dos veículos, tendo estoques adequados para rápidas e prontas substituições, e adquirindo por melhores preços material de consumo, combustiveis e lubrificantes.

Mas, nāo é só para permitir um custo global de operaçâo mais baixo que a Emprésa única se torna necessária e sim, principalmente, para que possamos ter o preço único e a possibilidade de racionalmente organizar os transportes de uma cidade. A lei das compensaçōes é, como vimos, o grande recurso 
de que se dispổe, para a organização dos transportes urbanos satisfazendo aos reais interêsses da coletividade, e ela só se pode aplicar monopolizando os transportes coletivos, a cargo de emprêsa única. Com múltiplas emprêsas e com exploradores individuais, cơno ocorre no Rio de Janeiro, a fórmula de suportar preço deficitário em determinado local ou em horas ou oportunidades más, quando se pode compensar o prejuizo com lucro auferido em outras ocasiōes e lugares, torna-se virtualmente impraticável.

A admissão do explorador individual no sistema de transporte coletivo é inconveniente, como inconveniente é o arrendamento que algumas emprêsas fazem de seus veículos e a forma de remuneração de quase tôdas as emprêsas de ônibus do Rio de Janeiro a seus motoristas, cujos salários decorrem em grande parte da renda que conseguem. Ora, nos serviços de utilidade pública, nunca os interessados diretos no rendimento do capital devem estar em contato com o próprio público.

o serviço que prestam, quando isto ocorre, năo se mantém no mesmo nivel de eficiência, chegando a ser de má qualidade, quando se apresentam condiçôes de prejuizo certo ou de menor lucro. Interessado direto no rendimento do capital e de seu trabalho, perde a serenidade, quando antevê situaçáo desfavorável; raciocina no imediatismo do lucro e jamais aceita os efeitos da lei das compensaçōes. Quem sofre é o público. Rejeitam alguns passageiros e disputam outros, cometendo uma série de violaçóes às normas de tráfego: excesso de velocidade, corte à frente de outros veículos, paradas longe do meio-fio, avanços de sinal etc. Tomemos, por exemplo, um micro-ônibus que saia do Leblon e se destine à Tijuca, na cidade do Rio de Janeiro. A escola da vida ensinou ao motorista de transporte coletivo, o mesmo que o engenheiro de transporte aprende na Faculdade: o lucro no transporte urbano depende muito da renovação de passageiros. Então êle usa artifícios, argúcia e inteligência. Deixa o letreiro pouco visível ao longe e só pára para quem, ainda sem ler o destino final do veículo, fizer o sinal de que deseja tomá-lo. Este passageiro saltará no trecho de itinerário comum a tôdas as linhas do Leblon e abrirá outra vaga para a ambicionada renovaçăo. As vêzes é a vestimenta do passageiro que denuncia esta possibilidade: o traje esportivo de uma moça ou senhora indica que náo irá para o centro da cidade, devendo saltar antes do Lido, em Copacabana (zona de grande demanda de lugares); o uniforme de um colegial ou a roupa de um operário revela justo o opodto, que tal passageiro atravessará a cidade e vai até quase o fim da linha, săo os chamados na gíria dos motoristas - "os pés de chumbo". O público sente os efeitos dêsse sistema e chama os motoristas, especialmente dos microônibus, de "fominhas".

Sendo inúmeros os proprietários de emprêsas e de um ou mais veículos, a fiscalização dos horários se torna mais dificil e mais onerosa e, por isto, a Prefeitura (como Poder concedente e, conseqüentemente, fiscalizador) falha na defesa dos interêsses da coletividade. As viagens passam a se subordinar ao lucro ambicionado pelo transportador, segundo a fórmula egoística, embora natural, de quanto mais lucro melhor, em vez de se subordinar às necessidades do próprio público, as quais devem ditar os horários e as freqüencias de veiculos nas linhas, durante as diversas horas do dia e da noite. 
Quem observa o serviço de ônibus em São Paulo, onde se instituiu a emprêsa única, a C.M.T.C., e o compara com o Rio, muitas vêzes estranha sem entender, porque lá os motoristas dos ônibus não cometem excessos de velocidade, não selecionam passageiros, rejeitando uns e disputando outros, não cometem violaçōes de tráfego com o objetivo evidente de maior lucro, não apresentam a aparente incoerência de retardar a marcha e até mesmo de estacionar para angariar passageiros, na saida de cinemas, teatros, ou grandes bailes por exemplo, para logo depois cometer uma série de excessos de velocidade, como ocorre no Rio de Janeiro.

A admissão dos livres atiradores de permeio com um ou mais concessionários de serviço de transportes urbanos constitui um terrivel mal. Impedem que os concessionários agüentem os ônus naturais de um serviço de transporte para tôdas as horas, inclusive as más, imposto no interêsse público, porque deixam de se beneficiar na justa medida, dos lucros compensadores das horas boas. Por isto, o serviço de ônibus no Rio de Janeiro piorou progressivamente, enquanto proliferaram os micro-ónibus, impròpriamente chamados "lotações". E como que a moeda má expelindo a moeda boa. Alguns empresários de ônibus se transformaram em proprietários de "lotações". Quem estuda, aliás, a história dos transportes coletivos urbanos nos Estados Unidos, observa que lá também sucedeu fato análogo, quando surgiram os chamados jitney bus competindo com os sistemas de bondes elétricos, sem os ônus de horários e freqüência de veículos nas linhas e disputando-lhes os passageiros. A consciéncia do absurdo terminou impondo deveres aos ônibus, acabando com o "maná de comer a carne, sem roer o ôsso do negócio", e os jitney busses desapareceram. Surgidos em 1914, começaram a ser abolidos nas diversas cidades norte-americanas, entre os anos de 1920 e 1930.

Múltiplas emprêsas e exploradores individuais de transporte coletivo existem no Rio de Janeiro e na maioria das cidades brasileiras. Fácil é, portanto, não só aos técnicos e autoridades responsáveis, compreender a extensảo do mal a corrigir, como, ao.próprio público que sofre com a desorganizaçâo reinante e sente nas observaçôes aqui consignadas, a explicação de muitos dos efeitoc que o aborrecem e mesmo atormentam.

Sem a emprêsa única é impossível coordenar convenientemente todos os meios de transporte coletivo de que necessita uma cidade.

\section{7 - A emprêsa única deve ser estatal, particular ou de economia mista?}

Como vimos, o preço único só é viável porque há compensaçōes e estas só săo possíveis dentro do regime de monopólio. Também as combinaçōes que a organização racional dos transportes exige só é viável com a emprêsa única. Ela pode operar mais econômicamente, porque tira partido do princípio económico da concentração, baixando o custo operacional por veículo e quilômetro rodado, já que o ônus dos serviços de direção e de manutenção baixa em relação aos veiculos operados e aos percursos realizados. Apesar das naturais prevençōes contra os monopólios, só monopolizando é possivel proporcionar ao Povo um bom serviço de transportes coletivos.

O público tem prevenção contra as emprêsas particulares monopolistas, concessionárias de serviços de utilidade pública e o Estado, em todo o Mundo, 
tem se revelado deficiente em sua indispensável ação fiscal das concessōes que admite. Por isto, a solução recomendável mais simples é a do monopólio estatal e não a da emprêsa privąa, operando no regime de concessão. Nos países de economia estabilizada e cujas cidades já não mais sofrem o impacto de vertiginoso crescimento provocado pela industrializaçāo, suportando simplesmente um crescimento vegetativo, a melhor soluçăo nos parece ser a do monopólio estatal, As grandes deficiências da emprêsa estatal, que sâo a falta de continuidade administrativa e o empreguismo, podem ser removidas colocando a Administração da emprêsa, livre das injunçōes e interêsses subalternos de políticos inescrupulosos, com certos artifícios, como por exemplo: eleição indireta dos diretores e presidente ou superintendente através de representantes de várias entidades ou classes da Comunidade; ou nomeação pelo Prefeito, dentre os elementos de sua confiança ou dentre os indicados na proporção de três para cada vaga, pela Câmara Municipal, mas em qualquer dos cascs, de forma a que o período do mandato, dos diretores e presidente ou superintendente seja bem superior aos perídos normais dos mandatos eletivos de prefeito e vereador, verbia Bratia, por doze anos. Desta forma se evitam as prejudiciais substituiçóes de direção e de certa maneira se proporciona maior independência à Administração da Emprêsa. Convém lembrar o que tem ocorrido com a C.M.T.C. de Sāo Paulo que, em 8 anos de existência, possuiu 14 superintendentes e tem sofrido do grande mal do empreguismo, em determinadas fases, segundo alguns depoimentos públicos.

Nas cidades brasileiras, como o Rio de Janeiro, que estăo sofrendo o impacto de crescimento vertiginoso e em ritmo de difícil, senăo impossível previsão, porque decorre êle da industrializaçăo e de outras condiçōes propiciadoras do desenvolvimento urbano, a solução deve ser outra.

O crescimento vertiginoso da populaçāo aumenta a demanda de transporte, extraordinàriamente, e de maneira tão imprevista quanto aquêle ritmo. Para atender a uma maior demanda, mais recursos financeiros são necessários. E êstes no monopólio estatal, vêm do orçamento. Este, sendo feito com dois anos de antecedência e sendo dificil realizar a correta projeçāo da demanda também o é a da receita orçamentária. A consequiência é a falta de meios adequados, nas oportunidades de atendimento das grandes demandas supervenientes. Deficiência esta tanto mais grave quanto sabemos ela ocorre em relação a necessidade de expansão de todos os serviços públicos, que precisam acompanhar o ritmo de crescimento da cidade.

A situação, quanto à falta de meios, se agrava em nosso País, devido à desvalorização da moeda, tanto maior quanto mais se pronuncia a ascensão da curva inflacionária e devido à fase de economia em desenvolvimento que atravessamos, na qual os recursos financeiros são solicitados para um sem número de empreendimentos que o Estado incentiva, realiza ou nos quais intervém.

Preferimos, por tudo isto, a fórmula da Emprêsa de Economia Mista, adotando-se, entretanto, uma nova concepção de orß̉anização, diversa da comumente adotada hoje. Em lugar dos cargos de direçăo ficarem na mão do Estado, devem êles ser entregues aos representantes do capital privado, ainda que êste não seja majoritário. Desta forma, resolvemos o ponto crítico da falta 
de continuidade administrativa. Ao Estado deve ser reservado tão sòmente o contrôle contábil da Emprêsa. Uma tal solução é capaz de incutir confiança ao Capital privado e assim resolver a crise da falta de recursos financeiros para assegurar a expansão dos transportes, de acôrdo com a crescente demanda. Esta aliás tem sido a grande deficiência da C.M.T.C. de São Paulo. Aproveitemos, portanto, o ensinamento. Por outro lado, justifica-se o contrôle contábil pelo Estado, porque fica assim assegurada a parte essencial que aconselha o intervencionismo estatal nos transportes coletivos, como serviço que é de utilidade pública, isto é, a possibilidade real de garantir ao Povo, a mais baixa tarifa justa.

O transporte coletivo nâo deve ser encarado como setor de distribuição indiscriminada da renda pública e năo deve ser gratuito, nem deficitário, mesmo na soluçāo do monopólio estatal. Precisa e pode dar lucro para atrair capitais e assegurar a expansão necessária. Como um dos serviços essenciais de utilidade pública, o consumo é certo e a renda absolutamente segura. Não havendo riscos de encalhe de mercadoria como no comércio comum, a margem de lucro, como de resto em todos os serviços de utilidade pública, pode e deve ser menor que em outros empreendimentos. A tarifa deve entăo ter êste sentido de justiça: atendimento equilibrado de dois interêsses antagônicos, pelo menos na aparência, isto é, a tarifa não deve servir de rápido e fácil enriquecimento de alguns, à custa da bolsa de todos, nem ser tâo baixa que mate o estímulo na expansão do serviço, porque assim o povo ficará sem adequados transportes.

Vimos que a insuficiência de meios, na soluçāo do monopólio estatal para os transportes urbanos, obriga ao recurso de atrair capital privado na fórmula associativa de emprêsa de economia mista.

A atração de capitais é tão importante que somos de parecer devemos calcular a tarifa justa para a Emprêsa de Economia Mista criada nos moldes supra, acrescendo um adicional de estímulo ao capital e assegurador da capacidade de expansâo. O adicional precisará ser tanto maior, quanto mais capital se necessitar para a expansão do serviço, no caso da municipalidade não ter recursos para cobrir tal deficiência, com meios retirados do erário público. O adicional se anulará sempre que não houver necessidade de expansāo ou, em outras palavras, carência de capital.

A constituição de uma Emprêsa de Economia Mista, encampando os meios existentes de vários exploradores dos transportes coletivos de uma cida. de, enfrenta um primeiro problema: o do desequilibrio entre o valor arbitrado ou avaliado do acervo material encampado das diversas emprésas ou proprietários e o valor real de material equivalente, mas que estivesse dentro da padronizaçâo que a nova Emprêsa deve adotar. Um segundo problema, decorrente aliás do primeiro, é que ela operará em condiçōes desfavoráveis, econômicamente, enquanto não tiver uniformizado seus diversos materiais. Por isto, 'somos de parecer que, em tais casos, não devemos querer que as tarifas venham a corresponder ao total do capital investido e sua amortização. Para que a nova emprêsa seja vigorosa e possa se expandir com uma tarifa baixa, deve ser descapitalizado o montante total ou parte dêle, que corresponda às açōes distribuidas à título de indenização do material encampado. 


\section{OS TRANSPORTES RODOVIÁRIOS INTERMUNICIPAIS OU ENTRE AS CIDADES}

\section{1 - Transportes coletivos}

A proporção que se melhơra o sistema rodoviário, os ônibus vâo assumindo papel preponderante como meio de transporte coletivo entre as cidades, servindo assim às zonas rurais que atravessam.

Nos Estados Unidos da América do Norte, em menos de um quarto de século da era automotorizada, os ônibus assumiram a liderança no transporte de passageiros entre as cidades. Enquanto na Primeira Guerra Mundial as ferrovias norte-americanas suportaram a carga do transporte de passageiros entre suas diversas cidades, no primeiro ano da última grande Guerra, os ônibus já chegaram a atender a mais da metade do total de viagens de passageiros entre cidades.

No Brasil assistimos dia a dia, mesmo nas zonas menos desenvolvidas do País, à invasão do veículo automotor como meio de transporte coletivo, não só naquelas regiōes não atravessadas pelas estradas de ferro, o que seria òbviamente natural, mas também onde os trens ferroviários de há muito vẻm prestando seus serviços.

São fatôres essenciais ao desenvolvimento dos ônibus nas ligações intermunicipais ou interestaduais: a liberalização das restriçōes de barreiras estaduais e municipais, a uniformidade nos regulamentos estaduais quanto aos veículos, o tratamento que se thes dispensar igual aos automóveis nas rodovias, a adoção de material moderno, de manutenção adequada e a melhor organizaçẩo possível dada às funçōes ersenciais do tráfego, durante o percurso através das cidades e nos pontos ou estaçōes terminais.

Nada é mais absurdo do que assistirmos, nas diversas barreiras estaduais e até municipais, à parada dos ônibus para fiscalizaçāo, fruto de orientação e de mentalidade atrasadas. E o caso de se perguntar aos defensores de tă absurda norma, se a alguém de bom senso ocorre fazer parar um trem quando a fronteira de um município ou de um Estado da Federaçāo é atravessada. Voltaremos ao assunto, mais adiante, ao tratarmos das barreiras.

\section{2 - Transportes de carga}

Os autocaminhões têm se desenvolvido, como meio de transporte, pela virtude que apresentam no campo da flexibilidade e conseqüente economia que proporcionam, evitando as baldeações onerosas. As baldeaçōes de carga, que os caminhōes evitam, em relação às cargas transportadas por estrada de ferro ou por embarcaçōes fluviais ou maritimas, economizam tempo, máo de obra e diminuem os riscos e danos e, consequientemente, as perdas materiais. Mas, embora seja inegável a vantagem da entrega direta da carga pelos próprios autocaminhōes que a apanharam no lugar de origem, diante do aumento crescente da capacidade de transporte dêles, nem sempre será vantajoso e mesmo possivel assim proceder, por isto as estaçōes terminais para caminhōes de carga passam a ter grande importância para os transportes rodoviários.

O desenvolvimento da rêde de estradas de rodagem, criando vias modernas do tipo canal de tráfego, ainda mais tem concorrido para evidenciar a necessidade de terminais para autocaminhōes de carga, porque tem aberto 
a êstes excelentes perspectivas no campo dos transportes terrestres.

A experiência norte-americana tem demonstrado que, em cada grande comunidade urbana, é preferivel concentrar os caminhões numa só terminal, do que os ter espalhados por várias pequenas terminais. As melhores terminais para caminhões de carga construidas até hoje são as do New York Port Autho. rity, em New York e Newark, nos Estados Unidos.

O objetivo de tais estaçōes é concentrar os grandes caminhōes, em local đe fácil manobra e operação de carga e descarga, quando as mercadorias transportadas não săo de um único destinatário. Assim procedendo, as cargas dos grandes caminhóes passam, na terminal, para a frota de pequenos caminhōes que opera na cidade, de acôrdo com o interêsse dos diversos destinatários que podem grupar mercadorias vindas em mais de uma unidade de transporte rodoviário, tornando a distribuiçāo urbana mais fácil e mais económica. Anàlogamente os pequenos caminhōes recolhem mercadorias $e$ as reunem nas Estaçōes Terminais, onde os grandes caminhōes dos transportes rodoviários se recarregam. Esste sistema evita que pesados caminhōes percorram as ruas da cidade para entrega parcelada de mercadorias, tão prejudicial do ponto de vista de economia dos transportes, quanto para o congestionamento do tráfego. As mercadorias de diferentes procedências e trazidas por diversos caminhōes, mas destinadas a uma mesma firma ou emprêsa, podem ser reunidas na terminal possibilitando, dentro da cidade, uma entrega mais económica e eficiente, pela concentração de cargas que possibilita. A: cargas de retôrno, para um mesmo destino, também podem ser consolidadas nas terminais, de modo a facilitar que os caminhōes deixem a cidade com cargas completas, obtidas no mais curto tempo possivel e, portanto, com maior proveito para o transportador. O serviço tornando-se, então, mais económico poderá oferecer fretes mais baixos.

As terminaį de autocaminhōes de carga devem ser localizadas de modo a ter boa conexão com o sistema de canais de tráfego que a cidade tenha ou venha a estabelecer, mas também devem ficar próximas de seus principais e mais prováveis clientes, grandes firmas industriais e comerciais, e estaçōes de carga das estradas de ferro, aeroportos etc. E lógico que a escolha de local para uma terminal e seu projeto, procurando a maior eficácia operacional desejável, devem obedecer às melhores consideraçōes de ordem técnicacientífica.

\subsection{Barreiras}

Nos pontos em que as estradas transpóem os limites políticos dos Estados e Municípios criaram barreiras com o intuito de exercer fiscalização federal, estadual ou municipal conforme os interessados no local. De um modo geral, a fiscalização se exerce de dois pontos de vista: o policial e o de rendas. Do ponto de vista policial cuidam do tráfego e de outros aspectos de seguranca pública, como porte de armas, tráfico de entorpecentes etc.

Essas barreiras constituem um entrave ao transporte rodoviário, baixando o rendimento quilométrico horário, e sua pretendida eficiência deixa muito a desejar. Quando era Diretor do Serviço de Trânsito no Rio de Janeiro em 1951, batalhei pela extinção das barreiras do Distrito Federal, visando principalmente a facilitar a entrada da produção agropecuária das regiōes que 
abastecem a Capital da República e pretendendo que, com o exemplo dado, os Estados e Municipios viessem a facilitar o tráfego rodoviário com idênticas medidas. Apesar de ter conseguido o concordo dos Chefes de Polícia e Prefeito da época, não tivemos a felicidade de ver concretizada a medida. Assumindo a Chefia de Polícia do Departamento Federal de Segurança Pública, em 27 de agôsto de 1954, procurei o concordo do Prefeito Engenheiro Alim Pedro e pude baixar portaria extinguindo, a 4 de outubro daquêle ano, as barreiras nas estradas de conexão do Distrito Federal com o resto do Brasil. Nunca imaginei que a simples extinção das barreiras no Distrito Federal tivesse tamanha repercussão favorável na opiniăo pública do interior do País. Entre as felicitaçōes recebidas através de inúmeras cartas e telegramas, destacamos a moção de solidariedade do Conselho Rodoviário Nacional e de Câmaras de alguns Municípios do Estado do Rio de Janeiro e de São Paulo.

Qual era a situaçāo das barreiras do Distrito Federal?

Havia os seguintes postos: no ponto de barcas para Niterói, na ponte da Rodovia Rio-Petrópolis, na ponte de Vigário Geral (da antiga Estrada RioPetrópolis), poucas centenas de metros além da bifurcação da Estrada das Bandeiras sôbre a Rodovia Presidente Dutra, na saída de Campo Grande sôbre a Estrada Velha Rio-São Paulo e, finalmente, na ponte do Guandu na Estrada de Santa Cruz.

Que serviço podia prestar a fiscalização policial naqueles postos?

O principal argumento que tem prevalecido, em defesa da manutenção dêles tem sido o de que êles desempenham o papel de crivo contra a evasão de automóveis furtados. Este é um serviço que as barreiras do Distrito Federal năo podem prestar $\mathrm{e}$, aliás, nunca efetivamente prestaram, porque durante todos os longos anos de sua existência nenhum carro furtado foi detido nos postos de barreira e muitos veículos furtados no Rio de Janeiro, foram mais tarde localizados em Minas, Estado do Rio de Janeiro, Sāo Paulo, Goiás, Paraná, Bahia etc., o que também significa que os ladrōes passaram incólumes por inúmeras barreiras, ou melhor que a existência delas não desempenhou qualquer papel de eficiência para a recuperação do automóvel furtado.

Não há um obstáculo natural contínuo entre o Distrito Federal e o Estado do Rio de Janeiro, com poucos pontos de passagem obrigatória, e por outro lado o crescente desenvolvimento das localidades situadas nos limites do Distrito Federal com os adjacentes Municípios fluminenses, proporciona um sem número de saídas capazes de desbordar as barreiras instaladas nas rodovias principais. Aumentar o número de barreiras para cobrir tôdas as possiveis passagens sôbre a fronteira do Distrito Federal é impraticável, tăo numerosas elas são. Por isto, o motorista em situação clandestina naturalmente desborda as barreiras conhecidas e alcança as estradas principais longe e livre delas. As barreiras desempenham então o pior papel: incomodar a todos que estão em situação regular e nâo obter resultados práticos de interêsse público, únicos que justificariam as restriçōes criadas à livre circulaçăo rodoviária. Aliás, antes de extingui-las, já os carros de passageiros nāo eram sistemàticamente fiscalizados e agora que, lamentàvelmente as restabeleceram no Distrito Federal, também os carros particulares, nem seus motoristas são fiscalizados; 
só os caminhões estão merecendo a atenção dos fiscais das barreiras e, sôbre isto, falaremos mais adiante.

As barreiras têm feito estatística dos veículos entrados e saidos, mas, para isto, bastam aparelhos registradores automáticos, pneumáticos e eletro-magné. ticos, sem que se instalem barreiras; aliás, não é só na fronteira que o volume de tráfego precisa ser medido.

As vêzes, pensam em desenvolver as barreiras como meio auxiliar de cobrança de multas de veículos e motoristas em débito. Os policiais ficam com listas para conferência dos números dos veículos em débito e só a êstes obrigam a parar. Analisando êste aspecto, quando Diretor do Serviço de Trânsito no Distrito Federal, verifiquei e ainda hoje penso da mesma forma que não é o aprimoramento daquela fiscalizaçăo nas barreiras, que deve ser procurado, e sim o aperfeiçoamento no campo das notificações e do sistema de contrôle e cobrança de multas. A quase totalidade dos motoristas, cujos carros estavam nas listas, eram realmente surpreendidos com muitas por infraçōes que desconheciam, por năo terem sido notificados no ato em que elas foram cometidas. Procurando tornar as notificaçōes como um dever sistemático da ação policial e agindo em qualquer ponto da cidade sôbre os recalcitrantes, com rapidez, energia e espírito de justiça, a necessidade daquele contrôle, em barreiras, desaparece completamente.

A fiscalizaçāo mais sistemática que se observa nas barreiras é sôbre os autocaminhōes de carga, os quais formam às vêzes extensas filas à margem da estrada, esperando pela vez da fiscalizaçăo. Os responsáveis pela instalação ou manutenção das barreiras devem se lembrar dos seguintes pontos:

1) A proporção que aumenta o transporte rodoviário, as filas dos autocaminhōes crescerão nas barreiras e se agravarăo os inconvenientes da concentração de uma fiscalização exercida num só ponto.

2) As barreiras municipais vêm se multiplicando, ano a ano, com o aumento do número de municípios e concorrendo para retardar as viagens dos autocaminhōes, com reais prejuizos para a economia do País.

3) A verificaçăo policial se o motorista está em situaçăo regular, quanto ao documento de habilitação, matrícula e registro na Repartiçâo de T.ânsito. quanto à quitação com o I.A.P.E.T.C. e com o impôsto sindical, nunca deve ser feita nas vias públicas, quando os veículos estāo circulando, salvo se tiverem cometido infraçăo. Sem inconvenientes e com vantagem no tocante à maior eficiência, essa fiscalização deve ser feita, nos locais onde os veículos costumam estacionar. Os caminhōes, por exemplo, se concentram na zona do mercado municipal, dos grandes armazens, na área do comércio atacadista, cais do porto etc., e ai devem ser fiscalizados, Nāo há prática mais errada do que manter guardas para, sistemàticamente, fazer parar veículos na via pública, com o fito de fiscalizaçăo da situaçáo do motorista e pior ainda quando se distraem para êste serviço, os motociclistas, que devem patrulhar e procurar os que cometem infração de tráfego. Os coletivos devem ser fiscalizados nos pontos terminais de percurso, nas estações se houver. E fácil concluir que a fiscalização de documentos, nos locais de estacionamento, nāo causará entraves à circulaçăo, o que nâo ocorre com a prática supra referida. Quando um veículo estiver circulando, seu condutor só deve ser intimado a 
parar por um policial, quando comete uma infração de tráfego, ou quando houver forte indício de estar em situaçāo irregular. Aliás, em tais casos, devem ser sistemàticamente detidos, fiscalizados, notificados ou autuados, conforme o caso. Mais de uma vez tive de instruir e advertir guardas, visando a orientá-los e compeli-los à prática correta de policiamento de tráfego, mas os maus hábitos dificilmente são abandonados e a eficiência da ação policial continua em nivel baixo no Rio de Janeiro, exigindo, sobretudo e por muitos anos, perseverança numa sadia orientação.

4) A fiscalizaçâo do ponto de vista rendas, ou contra a saída de deter-minados gêneros alimenticios, como às vêzes pretendida pela C.O.F.A.P, se baseia na conferência da carga dos caminhōes, o que conduz a uma situaçâo de forçosa desonestidade, por mais doloroso que seja registrar semelhante fato. Para conferir uma carga é preciso descarregá-la e sabemos ser inviável, numa barreira rodoviária, descarregar caminhōes pequenos de 6 toneladas, quanto mais os grandes caminhōes de 8, 10 e mais toneladas com reboques. Fica, então, o funcionário numa situaçāo de a priori cometer a desonestidade funcional de dar por conferido aquilo que não pode realmente conferir. $\mathrm{E}$ ainda é pior quando funcionários mais inescrupulosos passam a usar da verdadeira arma de extorsão que the puseram nas mãos, tirando dinheiro dos motoristas de caminhōes, com a triste expressão que já ficou célebre, entre êles: Passa (200 cruzeiros) ou vamos conferir a carga".

As autoridades interessadas na fiscalização de rendas, sejam municipais, estaduais ou federais, precisam se convencer de que estamos vivendo no século da motorização e que devem procurar outros processos de fiscalização, abandonando integralmente a de barreiras rodoviárias, por ser impraticável e prejudicial.

Finalmente, devemos salientar que:

1) O respeito às normas de tráfego se obtém através de adequado policiamento ao longo das vias públicas e não por determinadas exigências fiscais em barreiras. Quantos, na Rio-Petrópolis ou na Rio-Sāo Paulo por exemplo, só nāo entregam a direção dos veículos a pessoas inabilitadas que querem treinar, na ocasião de ultrapassar a barreira?

2) Em lugar de uma filtragem efetiva com o fito de verificar a dccumentação de todos os motoristas em barreiras desbordáveis (como são a maioria das situadas nos pontos que as rodovias transpôem os limites politicos dos municípios) deve-se para deter carros furtados ou um crimonoso fugindo em carro já identificado, estabelecer pôsto de vigilância em pontos de passagem obrigatória, embora inteiramente fora dos limites políticos dos Estados e Municipios, mantendo-os ligados com centrais de polícia, via telefone e rádio e com patrulheiros dotados de aparelhos radiofonia em seus carros, motocicletas ou servicars. Caberia aos postos de vigilância barrar e deter com a ajuda dos patrulheiros, " carro com as caracteristicas anunciadas nos avisos de alerta partidos da Central de Polícia, para onde devem convergir diretamente do páblico e sem perda de tempo tôdas as suas queixas. Aliás, a vigilância será muito ampliada com a cooperação das Estaçốes de Rádio-broadcasting que deverão irradiar imediatamente os avisos da policia sôbre carros furtados ou sôbre criminosos fugindo em carro identificado. O público deve ser continua- 
damente alertado que ao ouvir tais avisos deve, sem perda de tempo, telefonar para a Central de Polícia, informando onde viu o carro procurado e em que direção êle ia. A Central de Polícia, conhecendo a posição de suas patrulhas sôbre mapa da cidade ou regiâo, é capaz de apertar o cêrco e apanhar o criminoso. Também é digno de nota o efeito psicológico que se obtém sôbre o ladrāo de automóvel que fugindo com o rádio ligado, ouve o alerta que tôdas as Estaçôes de Rádio estejam transmitindo. Ele abandonará o veículo imediatamente, pois se vê perseguido por muitos olhos. Ainda de grande utilidade, nesse amplo sistema de vigilância, é a procura de cooperação dos postos de gasolina ao longo das rodovias, que devem ser instruícios quanto à conduta que devem ter em relaçăo às alertas ouvidas através das Estaçōes de rádio.

\section{ORGANIZAÇĀo DOS TRANSPORTES - COOPERAÇÃo DA ENGENHARIA DO TRÁ- FEGO - REPERCUSSÃO NO DESENVOLVIMENTO DA CIDADE E DA RÊDE RODOVIÁRIA.}

\section{1 - Os meios de transporte coletivo}

Entre os meios de transporte coletivo que servem hoje às cidades contam-se: o bonde de diversos tipos, desde o aberto usado no Rio de Jkneiro até os fechados, dos quais o mais moderno é conhecido pela sigla PCC, o trolley-bus ou trolley-coach, o ônibus, os trens suburbanos e os rápidos trens urbanos ou de metropolitano. Os trés primeiros sāo chamados por LESLIE WrLL.rams: transportes das ruas locais. Os rápidos trens urbanos são empregados quer a céu aberto, em estruturas elevadas ou em trincheiras, quer em subterrâneo, de qualquer forma em pista especializada e livre de interferências estranhas.

\subsection{1 - Que meios sâo necessários?}

Não dispondo de razoáveis dados estatísticos brasileiros, que permitam seguras conclusōes, julguei preferivel recorrer a dados elucidativos norte-americanos, que poderão auxiliar o leitor, principalmente nas previsóes dos planos de desenvolvimento do sistema de transporte coletivo urbano.

Excluindo os passageiros transportados por trens suburbanos e em rápidos trens urbanos, as pesquisas norte-americanas revelam as seguintes conclusōes:

1) Desde 1926 começaram a diminuir o número de bondes e a crescer o número de ônibus e de trolley-coach, êste último meio aliás só surgiu a partir de 1936.

2) Nas cidades de menos de 250.000 habitantes têm predominado os ônibus como meio de transporte. Já em 1946 seus passageiros representavam $2 / 3$ do total de pessageiros dos diversos meios de transporte coletivo urbano.

3) Nas cidades compreendidas entre 250.000 e 500.000 habitantes passaram a predominar os trolley-coaches, que nelas transportaram a metade dos passageiros.

4) Os bondes ainda têm subsistido bem, como meio de transporte, nas cidades de quinhentos e mais mil habitantes, pois $2 / 3$ do total de bondes exis. tentes nos Estados Unidos são encontrados naquelas cidades. 
Observando-se a estatística do total de passageiros de transporte coletivo, nos Estados Unidos, incluindo o bonde, o rápido trem urbano, o trolley-coach e o ônibus, verificamos a seguinte tendência: o número de passageiros transportados anualmente em trens urbanos (metropolitanos) mantém-se prticamente inalterável; decresce o número de passageiros transportados anualmente em bondes, à proporção que crescem os números dos transportados em ônibus e em trolley-coach. Estas observaçōes crescem de importância quando nos lembramos de que tem havido aumento substancial nos totais de passageiros e que também as diferenças de niveis têm sido absorvidas pelos ônibus c trolley-coaches, já que estacionário se mantém o total dos passageiros de trens urbanos e que diminui o total dos que utilizam bondes. Observando-se a estatística anual de 1926 a 1948 (nāo obtive dados dos últimos anos) relativamente ao número de unidades de transporte dos diversos tipos, verificamos uma marcante redução no número de bondes desde 1926; aumento do número de unidades de trens urbanos até 1938, quando então começaram a decrescer; aumento das unidades de trolley-coach e de ônibus. Em 1948, nos Estados Unidos, a proporção já era de 1 trolley-coach para 10 ônibus.

Os rápidos trens urbanos, subterrâneos ou nāo, são apresentados como soluçāo indispensável ao transporte de grande massa de passageiros, que ocorre nas cidades acima de um milhão de habitantes. Não devemos esquecer que a falta de flexibilidade que possuem năo exclui o transporte conhecido como de superfície (ônibus ou mesmo trolley-coach) para o desempenho do papel complementar de deixar próximo do destino o passageiro de metrô, que tiver saltado numa estação distante.

A verdade é que, numa grande cidade, uma rêde de canais de tráfego é indispensável, tenha ou nāo linhas de rápidos trens urbanos. Se o Administrador estiver no dilema de decidir na aplicação de recursos financeiros limitados, entre linhas de rápidos trens urbanos e criação ou desenvolvimento duma rêde de canais de tráfego, precisa, preliminarmente, realizar minuciosos estudos técnicos, à procura de fundamentos econômicos e realisticos, livre da interferência de interêsses subalternos, para escolher, em cada caso concreto, a solução mais conveniente, isto é, aquela que vier trazer maiores benefícios ao maior número de habitantes.

\subsection{2 - Qual a demanda de passageiros a atender?}

A demanda é tanto maior, em relação à população, quanto mais numerosa ela fôr numa cidade. Enquanto que nas pequenas comunidades calcula-se uma viagem diária para cada 5 habitantes, esta proporção vai aumentando até atingir uma viagem diária por habitante nas cidades acima de um milhâo de habitantes. Aliás, NASH já admite êste mesmo dado como prevalecendo nas cidades norte-americanas de mais de $\mathbf{5 0 0 . 0 0 0}$ habitantes.

Como sabemos, o transporte coletivo urbano tem particular significaçăo para os centros comerciais altamente concentrados das grandes comunidades. Pràticamente tôdas as linhas de transporte coletivo urbano conduzem ao centro da cidade, onde devemos ter a mais completa interconexāo de todos os meios do sistema de transportes empregados.

Há mais de vinte anos se pesquisam os dados capazes de focalizar o número de pessoas que entram na área central das cidades de diversos tams- 
nhos e delas saem diàriamente. Muitos são os fatôres que influem para que se pudessem obter conclusốes precisas e gerais, assim pensam cs técnicos americanos em relação às suas cidades. Não podemos entẫo, com mais razăo ainda, transplantar para as cidades brasileiras, onde surgem outras características diferenciais, as conclusóes obtidas para as cidades norte-americanas, como se fôssem verdades absolutas. Mas, inegàvelmente, as conclusōes que se seguem, na falta de outras mais precisas, constituem úteis indicações para os trabalhos de planejamento dos transportes de nossas cidades, quer como ponto de partida, quer para obtermos melhores dados à luz da experiência e de sucessivos reaịustamentos de acôrdo com a nossa realidade.

As principais conclusōes a que chegaram os técnicos norte-americanos podem ser assim resumidas:

1) Em pequenas cidades, de cada 5 pessoas que vão ao centro comercial da cidade, 4 delas utilizam seus próprios automóveis particulares.

2) Em cidades de tamanho médio, de cada 3 pessoas que vão ao centro comercial da cidade, duas delas utilizam seus próprios carros.

3) Em grandes cidades (acima de 500.000 habitantes) as conclusóes dependem de nelas existir ou não transporte rápido, como o proporcionado pelog trens urbanos:

- no primeiro caso, de cada 5 pessoas que vẩo ao centro comercial, quatro delas utilizam o transporte público;

- no segundo caso, de cada 3 pessoas que vão ao centro comercial, duas delas utilizam o transporte público.

Especialmente, nas médias e grandes cidades, os meios de transporte coletivo urbano constituem o principal meio de ligaçăo do público entre a residência e o local de trabalho de cada um. A maioria dos que vivem nas grandes cidades necessita de transporte público não só por conveniência, mas por absoluta necessidade, porque o uso do automóvel particular se thes torna difícil ou porque nāo possuem carro próprio. $O$ uso do carro particular vai se tornando cada vez mais oneroso, como também são crescentes as dificuldades de estacionamento no centro das grandes cidades.

Nos períodos de "rush" matutino e no fim do dia de trabalho, a curva da demanda de lugares nos transportes coletivos atinge seus picos. O planejamento dos transportes precisa então visar ao atendimento das necessidades dêsses dois períodos críticos diários. Nấo se deve contudo desprezar a conveniência de encorajar o uso dos meios de transporte público, pelo povo, fora daqueles períodos críticos, por motivos de ordem econômica, intimamente ligados à sobrevivência e ao desenvolvimento dos ditos meios.

\subsection{3 - Adoção de meios adequados.}

A principal lição a reter é que com equipamento moderno e apropriado e com aumento de frequêencia de serviço pode-se aumentar o uso dos transportes coletivos pelo povo, que se sente atraído por essas condiçōes favoráveis.

Muitas cidades estăo projetando ou realizando a completa ou parcial conversão das operaçōes de bondes para ônibus ou para trolley-coaches. 
Devido às características de flexibilidade do deslocamento sóbre rodas os ónibus e os trolley-coaches oferecem muitas vantagens sôbre os bondes, do ponto de vista tráfego, porque êstes ficam vinculados aos trilhos.

O ônibus apresenta certas vantagens inerentes às suas características, quando em confronto com o bonde: tem mais flexibilidade de itinerário, de embarque junto ao meio-fio, de melhor atendimento aos sinais luminosos de tráfego e de mais fácil ajustamento à demanda de lugares. Entretanto, a grande flexibilidade dos ônibus tem resultado em numerosos casos de indesejável extensão ou de desvio do itinerário. Deve-se ficar atento contra essas tendèncias que se podem tornar prejudiciais.

Mas, por outro lado, o moderno bonde, devido a se ter tornado silencioso, de operação suave com rápidas aceleraçăo e desaceleração, dotado de iluminação científica e confortável tem encontrado forte aceitaçāo do público onde foi inaugurado e tem sua aplicação particularmente recomendada no transporte de grande volume de passageiros. A escolha de ônibus, trolley-coacir ou bonde depende das características da carga, da análise dos itinerários e do custo operacional. Cada caso de conversâo cu de extensāo do serviço deve ser determinado pelas circunstâncias especificas. Não se pode pensar em melhorar os transportes sem conseguir a intima cooperação dos engenheiros de tráfego e dos diretores ou controladores dos transportes.

A renovaçáo dos veículos é de grande importância, nāo só para que melhor se adaptem às novas condiçōes materiais que se apresentam, como porque as pesquisas já provaram que o número de passageiros aumenta de $5 \%$ quando veículos velhos săo substituídos por novos, devido à preferência que o público dá a êstes últimos.

\section{2 - Principios fundamentais de orǵanizaçāo dos transportes coletivos}

O público de qualquer cidade precisa de transporte adequado às suas necessidades seguro, por preço razoável e que seja o mais baixo possível. Quando afirmamos adequado a suas necessidades, não queremos só caracterizar o tipo do meio de transporte, mas também a hora e o local de onde e para onde se transporta. Para que isto seja possivel é preciso organizar os transportes dentro dos seguintes principios:

1) A organizaçāo dos transportes coletivos deve procurar o emprêgo coordenado dos meios mais seguros e rápidos capazes de transportar o maior número de pessoas por unidade de transporte utilizada.

Segurança e rapidez são condiçốes essenciais, tão evidentes, que dispensam comentários,

Transportar o maior número de pessoas, por unidade empregada, decorre de uma imposição de ordem econômica, assim justificada:

- A tarifa será tanto menor quanto maior o número de pessoas transportadas, para um mesmo custo (direto e indireto) de operaçāo, correspondente a cada unidade de transporte.

- A diminuição do número de unidades transportadoras que frequentam as vias públicas, atendendo às necessidades de mesma carga de passageiros, 
redunda em economia das pistas, donde tráfego menos congestionado e menor probabilidades de acidentes.

2) E indispensável uma mesma direçāo e contrôle central para os transportes coletivos urbanos, para estabelecer e garantir um sistema único da mais racional e conveniente utilizaçāo dos meios de transporte de passageiros, em tôda a área coberta pela cidade.

3) O sistema de transportes coletivos de uma cidade deve estar intimamente coordenado com todos os planos e projetos relativos às funçōes de tráfego, à adaptação e ao desenvolvimento da própria cidade, e ao sistema de transporte que liga a cidade às zonas rurais e às outras cidades.

\section{3 - Duraçẩo das viagens - Horário e Frequêencia}

A importância do tempo das viagens, já em 1915 preocupava tanto a $\mathrm{F}$. W. DoolitrtLE, que ao tratar do "Cost of Urban transportation Service" salientava êle "o tempo está constantemente crescendo de valor..." É preciso contudo levar em conta que năo é simplesmente importante o tempo real consumido na viagem, mas o tempo perdido para o trabalho mental ou até mesmo para o descanso durante a viagem. Se esta fôr desagradável, perturbará a mente do passageiro durante todo o percurso, ao contrário, se o serviço fồ satisfatório, se as perturbaçōes e aborrecimentos forem abolidos das condiçōes do transporte, se o panorama fôr agradável, o passageiro desfrutará de um benéfico descanso e, não raro, sua mente pode continuar a trabalhar sem entraves ou dificuldades.

A organizaçäo dos horários dos meios de transporte é de suma importância, sua regularidade e conexão com outros horários devem ser observadas. As viagens esporádicas nāo interessam ao público e caracterizam um mau serviço. A rigorosa observação de horários se traduzem em regularidade e constância, duas condiçōes indispensáveis para caracterizar um bom serviço de transportes coletivos.

A velocidade e a regularidade do serviço de transporte são muito importantes para o viajar público. Por isto justificam-se tôdas as medidas que visem a tornar mais franca a circulaçăo dos veículos de transporte coletivo, como por exemplo: proibição de estacionamento que interfira com o deslocamento dos transportes coletivos; restriçōes de uso das vias públicas ou reajustamentos de itinerários que visem a diminuir as congestôes de tráfego; adequada divisão dos ciclos dos sinais luminosos e sua coordenação, de modo a possibilitar mais fácil escoamento aos transportes coletivos. Uma série de pequenós atrasos é capaz de irritar os passageiros e a eliminaçăo daqueles, ainda que em certos casos não representem grandes reduçōes do tempo de percurso da viagem, na verdade têm excelente efeito psicológico, dando a impressão de maior rapidez do que a realmente obtida.

A preocupação a êste respeito deve ser ainda maior para com os meios de transporte coletivo que transportam a maioria dos passageiros. Assim, enquanto o bonde fôr o principal veículo de transporte público, como em outras cidades ocorre no Rio de Janeiro, os responsáveis pelo tráfego devem procurar eliminar ao máximo todos os injustificáveis entraves a melhor rendimento da velocidade dêles. Nas vias frequientadas por bondes, em tais cidades, 
os responsáveis pela direção e contrôle do tráfego devem organizar a sinalizaçáo luminosa no sistema progressivo, tendo em vista assegurar ao deslocamento dos bondes a melhor çontinuidade possível, organizar a sinalização de certos cruzamentos especiais para aí facilitar ao máximo a vazāo dos bondes, pró́bir o estacionamento de carros particulares ou de aluguel como o fizemos nas ruas da Carioca e da Assembléia, em 1950, no coraçâo do Rio de Janeiro, conseguindo multiplicar por três a velocidade do percurso dos bondes entre as Praças Tiradentes e Quinze de Novembro, não admitir māo única nas vias onde o tráfego de bondes precisar se manter nos dois sentidos, porque será fatal o bloqueio do bonde de sentido contrário pela corrente de tráfego motorizado que se tornar volumosa, como constatamos entre vários casos nas ruas Voluntários da Pátria e São Clemente, nas ruas Marquês de Abrantes e Senador Vergueiro e Avenida Nossa Senhora de Copacabana, no Rio de Janeiro.

A respeito de organização da sinalização de certos cruzamentos especiais para melhor atender aos bondes e outros meios de transporte coletivo, não existem regras rigidas. $O$ estabelecimento de tempos especiais e distintos para atender o movimento dos bondes, como fizemos em 1950 nos cruzamentos da Avenida Presidente Vargas com as pistas laterais da Praça da República, no Rio de Janeiro, oferece maior proteção para os movimentos dos bondes através do cruzamento, mas às vêzes um tempo especial para a volta dos bondes, se de um lado favorece a êstes, de outro lado reduz a capacidade de vazäo total do cruzamento porque, nem sempre, os bondes nêle se apresentam no adequado momento da fase do ciclo em que êles poderăo prosseguir ou dobrar.

Uma correta organização dos sinais luminosos de tráfego, dentro de uma técnica moderna e adequada, capaz de eliminar as congestões de tráfego, tende a promover regularidade de serviço, que é fator importantíssimo de atração para que o público recorra ao transporte coletivo em lugar de aos meios de transporte individual. Regularidade de serviço também resulta numa mais equilibrada distribuiçăo da carga de passageiros, pela uniformidade de distribuição de lugares oferecidos, diminui o tempo médio de espera por transporte e aumenta o confôrto dos passageiros. $\mathrm{O}$ acúmulo de veículos de transporte coletivo, deixando grandes vazios entre os grupos assim formados, resulta em deficiente aproveitamento dos meios empregados, nẩo só porque causa excesso de lotação e irrita os passageiros com prolongadas esperas, como também porque em determinados locais e oportunidades fica oferecendo mais lugares do que a demanda exige.

A proibição de voltás à esquerda e a de tráfego em cima das linhas de bonde, nas vias de sentido duplo, são medidas que, quando aplicáveis, diminuem os atrasos dos bondes e aumentam o rendimento da velocidade prática.

A fiscalização rigorosa do estacionamento em fila dupla e mesmo da total proibiçăo de estacionamento, onde necessário aboli-lo, é de grande utilidade para manter elevado o rendimento da velocidade média dos transportes coletivos, sem falarmos do concurso que presta à diminuição dos acidentes.

Planejar o tráfego, nas vias frequentadas por apreciável número de transportes coletivos, levando em conta considerações como as que acabamos de fazer, concorrerá para melhorar a eficiência dêles. Não nos devemos esquecer de que de um modo geral gritam e reclamam os proprietários de carros 
particulares, muito mais do que o grande público que utiliza os transportes coletivos. A detesa dêstes repousa, entăo, na capacidade de discernimento e na consciência das autoridades responsáveis pelo tráfego que devem evitar as ilusórias soluçôes que beneficiam os passageiros de transporte individual ou de menor capacidade transportadora, à custa de piorar o rendimento de transporte dos principais meios de que a cidade dispóe para o transporte de grandes massas.

Certos regimes de serviço comprometem o rendimento da velocidade média e devem ser abolidos, ou melhor, reformados, como, por exemplo, no Rio de Janeiro, onde o sistema de fiscalizaçăo dos bondes abertos em que os fiscais retêm os bondes para suas conferências e em que os motorneiros retardam a marcha não só para tal fim como também para que um mesmo fiscal, que vem em bonde de sentido contrário, possa apanhar o veículo. Aliás, a meditação sôbre êste assunto leva-nos à convicção de que é indispensável o fechamento dos bondes, a abolição dos pingentes e a cobrança em caixa feita no ato da entrada ou da saída dos passageiros. Com uma tal reforma no sistema do transporte de bondes no Rio de Janeiro, teriamos maior velocidade quilométrica horária nas viagens de bonde, maior oferta de lugares hora e os passageiros transportar-se-iam mais confortàvelmente e em menor tempo. $O$ beneficio nấ ficaria adstrito aos bondes e seus passageiros, pois aos demais veículos seriam oferecidas melhores condiçóes de utilizaçăo das vias percorridas por bondes.

\section{4 - Escalonamento de horários de trabalho}

Não resta dúvida que o escalonamento dos horários de trabalho numa cidade auxilia muito no alívio do tráfego, nos comuns períodos de pico de cada dia útil. Entretanto, tal escalonamento muito prejudica o planejamento dos negócios em geral e muitas das relaçóes humanas e comerciais. Só se pode esperar êxito, em tais escalonamentos, se seu estabelecimento e justificativa forem muito bem estudados, à luz de dados estatísticos irrefutáveis e completos e se antes de pôsto em execução houver adequado e efetivo esclarecimento da opiniâo pública, através do desenvolvimento de um amplo e verdadeiro programa educativo.

\section{5 - Coordenaçāo}

E indispensável que todos os meios de transporte coletivo da cidade sejam convenientemente coordenados, formando como que um todo, um sistema único e perfeitamente conjugado com os planos e disposiçôes ligadas ao atendimento das clássicas funçốes do tráfego.

O grande perito em transportes CHARLES GoRDon expressou numa simples mas significativa palavra - coordenação - todo o futuro do planejamento dos transportes. Coordenaçẩo dos transportes entre si e também da utilização das vias públicas e do planejamento da cidade.

E dificil promover a melhoria dos transportes coletivos, a menos que haja cooperação inteligente e esclarecida, entre as autoridades responsáveis pela. desenvolvimento da cidade, pelos transportes e pelo tráfego. 
Um estudo comparativo e real do que se passa nas cidades norte-americanas mostra a necessidade e a vantagem da unificação dos sistemas de transportes, enquanto prevalecerem concessōes dadas a mais de uma emprêsa de transporte, Múltiplas concessōes' causam operação inadequada e retardam o melhoramento e a modernização do serviço.

No Brasil, as cidades do Rio de Janeiro e São Paulo, ambas da ordem de três milhôes de habitantes e nas quais estăo admitidos, respectivamente, os dois sistemas antagônicos: pluralidade de emprêsas e unificaçāo ou emprêsa única, servern para exemplificar os grandes inconvenientes daquele e as vantagens do último, bem como para reconhecer que a soluçâo mais recomendável não deve insistir nos erros cometidos com a criaçăo da C.Ṃ.T.C. de São Paulo, que têm sido de ordem administrativa e financeira, decorrente da forma adotada na constituição da emprêsa de economia mista.

\section{6 - Itinerários, paradas e terminais}

Os itinerários dos transportes coletivos têm muitas vêzes uma influência direta na eficiência operacional do sistema.

Estudos preliminares e de verificação devem apurar se os itinerários

: escolhidos atendem à conveniência da clientela e também se eliminam ao máximo possivel os atrasos e as interferências recíprocas entre o transporte coletivo e outros tráfegos.

Para atrair a clientela, os itinerários devem ser razoàvelmente diretos, acessíveis aos passageiros e aplausíveis durante o percurso.

Inicialmente e porque os bondes eram os únicos meios de transporte coletivo, era comum que suas linhas atravessassem as principais ruas do centro comercial das cidades, mas os bondes começaram a entravar o tráfego motorizado e houve necessidade de replanejar seus itinerários, visando a uma meihor distribuição dêles na zona central, procurando uma descentralização capaz de concorrer para o descongestionamento. Entretanto, as cidades que ainda mantêm os bondes como principal meio transportador de grande massa de passageiros, têm se visto assoberbadas com o elevado custo da colocaçâo de novos trilhos, que as modificaçōes de itinerários exige. O grande público chega mesmo a não compreender como certas soluçóes tão evidentes para melhorar os itinerários dos bondes não são prontamente tomadas; é que êle nunca leva em conta o custo das alteraçóes que a instalação de novas linhas exige. Em algumas cidades, a descentralizaçäo tem sido conseguida, encurtando certos percursos de bonde, de modo a evitar que todos êles atravessem o coração da cidade, diminuindo a frequêencia de bondes nos itinerários que percorrem as ruas centrais, dispersando os itinerários na área central, ou entāo substituindo os bondes por ônibus ou trolley-coaches. No Rio de Janeiro, os bondes deixaram de ir todos à Praça 15 de Novembro. Alguns já retornam da Praça Tiradentes ou da Praça Mauá e em futuro não distante, por certo, voltarăo da Praça da República. Os da zona Sul da cidade de há muito retornam do Tabuleiro da Baiana e não mais da Galeria Cruzeiro e a tendência natural seria fazê-los voltar do Passeio Público, nāo estivesse a Cia. Jardim Botânico de Carris na fase final do contrato de concessāo. 
Em matéria de planejamento de itinerários não há remédios padrōes e um dos fatôres a considerar, na Zona Central, sâo as disponibilidades quanto a pontos terminais que nāo perturbem o tráfego em geral no coração urbano.

A capacidade técnica dos engenheiros encarregados saberá, estudando e diagnosticando as causas das congestöes a resolver, encontrar as melhores ou as mais convenientes soluçōes, seja refundindo os itinerários, seja restringindo as voltas à esquerda por coletivos em vias de duplo sentido, seja evitando cruzamentos dos itinerários dos coletivos, seja descentralizando suas paradas, seja melhor distribuindo seus pontos terminais, seja fazendo os transportes coletivos retornarem do Centro em vez de atravessá-lo ou o inverso, sopesando todos os prós e contras, à luz de dados concretos observados e avaliados.

Já nos referimos às razōes que ditam a escolha de linhas simples e de linhas duplas. Do ponto de vista de congestionamento do tráfego na zona central das cidades, é perfeitamente discutivel se as linhas simples de ligação bairro-centro ou as linhas duplas de bairro a bairro através do centro, constituem ou não a melhor solução. A linha simples oferece a vantagem de um serviço mais uniforme, por liberar os veículos da interferência do tráfego das zonas opostas de uma cidade, a que se sujeitam as unidades das linhas duplas. Não raro, entretanto, o tempo adicional de manobra e de espera na zona central da cidade, já congestionada, sacrifica a eficiência procurada com a linha simples e aumenta o custo de operaçăo, pelos maléficos efeitos da congestão, sempre que năo houver suficientes disponibilidades de terminais capazes de não interferir com o tráfego das vias públicas pròpriamente ditas, utilizadas pela circulação na área central.

Os itinerários utilizando vias de sentido único facilitam muito a circulacão, especialmente nas cidades de vias estreitas, mas não há dúvida que, do ponto de vista transporte, constitui desconforto para os passageiros em geral, que se vêem obrigados a caminhadas tanto maiores, quanto mais afastados estiverem os itinerários de sentidos opostos. Só se deve recorrer então a tal solução, quando a manutençâo dos itinerários em vias de sentido duplo constituir verdadeira impossibilidade operacional pela congestão revelada. Foi precisamente o que ocorreu no centro do Rio de Janeiro. Não devemos contudo esquecer que o sentido único, uma vez estabelecido, deve prevalecr para todos os vículos que freqüentam a via e não sá para os automotores.

Enfim, o planejamento dos itinerários não pode esquecer todos os detathes operacionais já referidos, como o uso de talốes de transferência, sistema de áreas seletivas e regime expresso, pela repercussảo que todos êsses pormenores têm sôbre êles. Os itinerários decorrem fundamentalmente das disponibilidades que as vias oferecem e da disposiçâo que apresentam, no conjunto de tôda a área urbana e mesmo suburbana. O planejador năo pode deixar de considerar se a cidade pertence ao tipo tabuleiro de xadrez, longitudinal ou radial em leque; se ela possui ruas ou avenidas diagonais ou simplesmente vias públicas perpendiculares entre si; se a cidade já dispỗe de um sistema arterial de vias do tipo canal de tráfego; e qual é a localização dos bairros residenciais em relação aos centros comerciais e industriais, subcentros comerciais etc. 
Outro fator importante a considerar é a inevitável evoluçāo dos centros de populaçăo e dos bairros residenciais, comerciais e industriais, pois serão necessários, de tempos em tempos, rever os itinerários e reajustá-los às novas conveniências e necessidades, entre as quais devemos salientar o atendimento de viagens sem baldeaçōes para o maior número possível de passageiros, o que exige perscrutar as necessidades do público, através de oportunos inquéritos de origem e destino de passageiros.

A localizaçăo das PARADAS é fator importante na segurança e eficiência do movimento do tráfego, como vimos no capitulo especial ao tratar da função embarque e desembarque de passageiros. As paradas estão intima. mente ligadas às operaçōes de transporte e devemos ter todo o cuidado em seu planejamento.

O funcionamento de pontos terminais de ônibus junto aos meios-fios, tão generalizado em nossas cidades, criam condiçōes desfavoráveis para as funçōes de tráfego e năo agradam quer aos passageiros, quer ao público em geral.

Nos pontos finais das linhas, onde os ônibus são abastecidos e onde êles entram em contato com as vias férreas ou com outros importantes meios de transporte e também em áreas de grande acúmulo de passageiros é recomendável promover a instalação de terminais que permitam a realização de vultosas operaçóes de embarque de passageiros, mantendo-os protegidos da inclemência do tempo, enquanto esperam transporte, e evitando congestionar cs passeios e as pistas das vias públicas. Adequadas descentralizaçōes de paradas de ônibus e de outros meios de transporte coletivo, em faixas paralelas ou em bainhas sucessivas, permitem serviço independente e simultâneo das diferentes linhas do sistema de transporte sem as reciprocas interferências, tão prejudiciais ao rendimento operacional das diversas unidades de transporte.

Estações terminais são indispensáveis à organizaçăo de um bom sistema de transporte coletivo. Elas são necessárias não sòmente para os transportes coletivos interestaduais e intermunicipais, como para os urbanos e suburbanos. A principal finalidade das terminais nas zonas centrais das cidades é facilitar as reciprocas transferências de passageiros, num ambiente de confôrto e segurança, sempre que as baldeações assumirem elevados indices. Elas se tornam tâo mais indispensáveis, quanto mais elevados forem êsses indices. A outra finalidade da terminal é acomodar os meios de transporte durante os periodos de espera nos pontos iniciais ou finais de percurso, evitando que um excessivo número de veículos reunidos em área reduzida venha a congestionar as vias públicas, projetadas para atender o tráfego e nāo para servir de Estaçáo ou Parque de veículos.

A localizaçăo das terminais para os ônibus interestaduais e intermunicipais, deve permitir a fàcil transferência de seus passageiros e bagagem para os transportes coletivos urbanos e vice-versa. Sempre que possivel, uma única terminal numa cidade é preferivel a uma série de terminais, mas a localização dela, em relação ao sistema de vias de comunicaçōes, aos itinerários dos diveraos coletivos e a todo o sistema de transporte coletivo urbano é de importância capital. Estudos e pesquisas de volumes de passageiros, suas origens e des- 
tinos, interrelaçōes entre os transportes coletivos urbanos e os intermunicipais, embarque e desembarque e outras características de tráfego devem comandar - localização, o projeto e a operação das terminais.

\section{7 - Papel e importância dos canais de tráfeğo no campo dos transportes}

Os canais de tráfego são capazes de proporcionar perspectivas inteiramente novas ao aperfeiçoamento do sistema de transportes coletivos urbanos.

Desenvolvendo linhas duplas de trilhos para trens urbanos na faixa central dos canais de tráfego e utilizando as faixas laterais para os ônibus e mesmo trolley-coaches, é possivel obter-se uma integração dos diversos meios de transporte coletivo com o máximo de segurança, rapidez e rendimento. Cada canal de tráfego, assim utilizado, representa em relação a sua área de influência, a espinha dorsal dos transportes, para a qual convergem os passageiros e os transportes locais e de onde êles próprios irradiam para alcançarem seus diversos destinos.

A conexăo dos canais de tráfego com as vias locais da zona central precisa ser muito bem estudada do ponto de vista rendimento e necessidade dos transportes e, muitas vèzes, pistas especiais para uso exclusivo de ônibus, bondes ou trolley-coaches, além das privativas dos rápidos trens urbanos, tornam-se indispensáveis para a ligaçăo entre as faixas do canal de tráfego e as vias principais do coraçâo da cidade, de modo que os passageiros possam atingí-las ou nelas serem recolhidos, diretamente, ou através de uma Estação Terminal, a serviço dos meios de transporte coletivo e de seus passageiros.

Tendo em vista a utilidade dos canais de tráfego para os transportes coletivos, os projetos devem nāo só permitir a operaçao dos diversos tipos de transporte coletivo em uso ou desejados pela Cidade, como prever traçados que aproximem os canais de tráfego de áreas de grande número de passageiros potenciais, em vez de as evitarem.

De um modo geral, qualquer projeto de canal de tráfego adequado ao movimento do tráfego em geral, também deve servir à circulação dos ônibus, mas, naturalmente, as estruturas e os gabaritos dos canais de tráfego devem visar a atender aos atuais ônibus e prever os de que disporemos no futuro, maiores e mais velozes com certeza. O comprimento dos ônibus e seu raio de curva devem ser particularmente considerados nos projetos dos ramos internos das curvas e rampas dos trevos e outras conexōes que possibilitam a continuidade de movimento nos canais de tráfego. Raios máximos de curvas e mínimos aclives, coerentes com os aspectos econômicos dos projetos, devem ser preferidos e as larguras das filas devem ser suficientes para acomodar um ônibus ao fazer a volta sem ocupar mais de uma fila da faixa de tráfego.

Os canais de tráfego se prestam muito bem ao melhor partido que se pode tirar do regime de operaçāo do tipo expresso com os ônibus. Para isto é preciso que os canais sejam projetados considerando as sugestóes e as necessidades indicadas pelo engenheiro de transporte. O embarque e o desembarque de passageiros e especialmente a transferência dêles, de meios locais para veículos expressos e vice-versa, exigem projetos especiais. Como os ônibus 
nunca podem parar nas filas das faixas de tráfego continuo do canal, as bainhas ou desvios são indispensáveis, quando năo mesmo estação de ônibus independente das faixas de circulaçăa do canal pròpriamente dito. Provàvelmente o mcio mais simples de atender a transferência de passageiros de linha expressa para linhas de distribuição local e, vice-versa, seja o ônibus da linha expressa deixar o canal de tráfego num determinado ponto de conexăo com vias locais, onde ainda esteja em mesmo nível, para numa delas parar e permitir o intercâmbio de passageiros com os meios locais de transporte, retornando em seguida ao canal de tráfego. A desvantagem desta acomodaçăo reside no tempo extra que o ônibus expresso passa a perder em relação ao que seria necessário a paradas em nível diferente de uma transversal ao canal, da qual provenham ou para a qual se destinam passageiros. Neste último caso a localizaçăo da parada de ônibus expresso fica geralmente dentro da própria estrutura que suporta a via transversal onde opera um serviço de ônibus ou bondes locais. Há neste caso a desvantagem das subidas e descidas de escadas ou rampas pelos passageiros que fazem as baldeaçōes e, comumente, tornam-se indispensáveis barreiras eficientes para evitar que os passageiros ao saltarem de um expresso não se vejam tentados a cruzar as faixas da pista do canal de tráfego, visando a alcançar o lado oposto. Esta tentação aliás será tanto maior, quanto mais extenso fồ o circuito que rampas e escadas criem, em relação ao destino dos passageiros.

Minuciosos estudos de origens e destinos de passageiros devem ser realizados antes de projetar um canal de tráfego, de modo que o engenheiro rodoviário e o de transporte possam verificar qual será o beneficio que o projeto definitivo proporcionará à coletividade.

Os tipos mais comuns de operação de ônibus nos canais de tráfego săo os seguintes:

1) Os ônibus circulam através de vias locais de uma área ou bairro residencial, comercial ou industrial e depois de acumular sua carga de passageiros entram no canal de tráfego para através dêle alcançar diretamente seu destino distante. Vice-versa, deixam o canal de tráfego para distribuir os passageiros pela área ou bairro a que servem.

2) Os ônibus circulam pelo canal de tráfego só parando em pontos ou estaçōes bem distanciadas entre si (Detroit preferiu um escalonamento de $3 \mathrm{~km}$ ). Estes pontos ou estaçōes servem para o intercâmbio entre o serviço expresso ao longo do canal e os serviços de ônibus ou bondes locais.

3) Detroit tem utilizado um sistema especial. Durante as horas de "rush" matutino, os ônibus partem de uma série de terminais escalonadas de $3 \mathrm{~km}$, ao longo do canal e, sem parar, demandam a Estaçâo terminal na Zona Central. Em outros períodos de pico de tráfego, procede-se de maneira análoga. Fora dos períodos de pico de tráfego, ou seja nas horas mortas do dia ou da noite, tardes de sábado, domingos e feriados, os ônibus partem das terminais extremas de cada canal e param ao longo de seus itinerários, nas diversas terminais intermédias, para receber ou descarregar passageiro, no intercâmbio com os meios locais de transporte.

Finalmente, a escolha do sistema de operação dependerá muito da distribuiçāo da população e de seus hábitos de viagem. 


\section{TRANSPORTES ESPECIAIS}

\section{1 - Transportes coletivos irregulares}

Consideramos transportes coletivos irregulares todo o transporte de passageiros feito em veículos inadequados a êste tipo de carga. Assim, todo o transporte de passageiros em autocaminhăo, seja nas áreas urbanas e suburbanas ou no tráfego interestadual (os já comuns "paus de arara") deve ser considerado irregular. Não irregular pelo simples fato de que o veículo teria sido licenciado para carga de mercadoria ou material e está transportando passageiro, mas sim porque săo precárias suas condições de segurança, se não quiséssemos falar também do insuficiente confôrto que proporciona.

A realidade no Brasil é que a precariedade de meios apropriados ao transporte de passageiros tem conduzido à utilização e mesmo à admissão do autocaminhăo transportando pessoas, até dentro das cidades, quanto mais entre estas e também nas zonas rurais e suburbanas.

Enquanto perdurar a situação de insuficientes meios de transporte coletivo, o transporte de passageiros em caminhōes deve ser admitido, sob a expressa condição e bem fiscalizada de que todos os passageiros se conservem sentados, em bancos devidamente adaptados à carroceria do caminhảo. $\mathrm{O}$ maior perigo reside no transporte de pessoas em pé, sôbre o tablado da carroceria, porque além de alto, fica o centro de gravidade por demais instável, acarretando ou propiciando as mais sérias capotagens.

Além disso, em hipótese alguma, por melhor que seja a estrada deve-se admitir a tais veiculos, uma velocidade superior a $40 \mathrm{~km} / \mathrm{h}$.

\section{2 - Táxis ou carros de praça}

O transporte individual de passageiros de que o público pode dispor nas diversas cidades é realizado em táxis ou em carros de praça. Os táxis tomaram o nome do aparelho "taximetro" que marca o quanto deve pagar o passageiro, em funçāo dos quilômetros e centenas de metros percorridos, segundo a tarifa aprovada pelo poder público. Quando o carro fica parado mas à disposição de um freguês, o taximetro marca o quantum a pagar em função dos minutos decorridos.

Pelo "Código Nacional de Trânsito" os carros de aluguel das cidades de mais de 500.000 habitantes devem ter taximetro. As cidades de menor população têm simplesmente carros de praça, isto é, veículos em que o aluguel é pago por corrida realizada, seja ela pequena ou grande, numa mesma zona. Neste sistema o quantum costuma ser fixado em relação à distância máxima dentro da zona correspondente, de modo que tôdas as viagens menores são ainda mais lucrativas para o motorista e portanto é sistema mais oneroso para - passageiro do que o regime taximétrico. A terminologia "carros de praça" decorre do fato dos carros de aluguel inicialmente se terem concentrado em Praças Públicas, muito embora hoje haja pontos de estacionamento em outros logradouros públicos.

Também tem sido discutido se os carros de aluguel devem pertencer a uma só emprêsa, a várias emprêsas ou a motoristas individuais. 0 estudo da questão aconselha que se assegure a coexistência de uma ou mais emprêsas 
e de motoristas individuais. Com emprêsas é mais fácil manter o serviço em oportunidades de menor lucro, do que quando o serviço fica só na mẩo dos motoristas proprietários ou arrendatários dos veículos. Havendo emprêsa concessionária pode-se, através de contrato de concessão, exigir um mínimo $\mathrm{X}$ de veículos à disposição do público mesmo nas horas ou ocasiōes desvantajosas. Sem uma obrigação contratual fiscalizada, sob a ameaça de enchentes, de possiveis congestionamentos por ocasião de grandes festividades públicas, de trabalho com remuneração inferior à de outras horas, a consequêencia lógica e fatal é a retração dos carros, com prejuizo para o público que fica sem táxis.

Dentro do perímetro da zona central das grandes cidades, nāo se deve permitir a reserva de táxis, pelo menos nas horas de almôço e de fim do dia de trabalho, porque é a única forma possivel de assegurar transporte para quem o desejar, a qualquer hora e especialmente naquela em que os motoristas de táxis têm interêsse em selecionar passageiros para seus locais de residência ou de recolhimento dos carros. A reserva de táxis na zona central torna impraticável a fiscalização que visa a manter os carros à disposição do público em geral, Não havendo essa proibição observa-se nas proximidades da hora de almôço e de fim do dia de trabalho um grande número de táxis imobilizado no centro da cidade com a bandeira arriade, declarando-se ocupados. Alguns de seus motoristas são realmente faltosos, porque simulam a ocupação, permanecendo na proximidade de pontos de táxis para só aceitarem fregueses para bairros que lhes convenham ou para pleitearem preços acima da tabela vigente, quando não para ambas as coisas. Outros estão realmente aguardando um freguês certo, que irá para onde lhes convém Mas, para isto, o carro fica uma e duas horas imobilizado, sem servir ao público e o freguês certo nem sequer paga esta imobilizaçăo, por que ela é do interêsse do próprio motorista. Inúmeros carros ficam reservados, enquanto durante uma a duas horas poderiam ter servido a elevado número de fregueses.

A tendência observada em grandes cidades é a da extinçāo dos pontos de estacionamento de táxis na zona central, onde há grande demanda de táxis, mas, no Brasil, ainda não chegamos a êsse ponto.

A falta de limitação do número de táxis ou de carros de praça numa cidade acarreta menores possibilidades de trabalho efetivo durante o tempo que o motorista fica à disposição do público, com isto as tarifas baixas não lhes satisfazem por não propiciarem razoável proventos para o sustento da familia. Paris e Buenos Aires, por exemplo, limitam atualmente o número de seus táxis e naquela cidade foram os próprios profissionais que exigiram das autoridades uma limitação que a necessidade thes indicava.

O emprêgo da radiofonia a serviço de táxis, assegurando rapidez e facilidade de entendimentos entre a freguesia e os veículos, através de Centrais, para onde telefônicamente devem convergir os pedidos do público, é capaz năo só de melhorar a qualidade do serviço, como de torná-lo mais econômico, dando, portanto, um maior lucro dentro de uma mesma tarifa, o que convém ao público $\mathrm{e}$ aos motoristas profissionais.

O regulamento baixado para o Serviço de táxis no Distrito Federal, com - Decreto 31.181 , de 25 de julho de 1952, publicado a 31 daquele mesmo mês no Diário Oficial, constitui o resultado dos estudos e da experiência de vários técnicos, reunidos em Comissão que tive a honra de presidir. 